GEOUSP - Espaço e Tempo, São Paulo, No 28, pp. 125 - 150, 2010

\title{
FORMAÇÃO SÓCIOESPACIAL DA REGIÃO DE ARAÇATUBA NA PRIMEIRA METADE DO SÉCULO XX
}

Danton Leonel de Camargo Bini*

\section{Resumo:}

Neste trabalho é apresentado a história da ocupação do espaço geográfico regional de Araçatuba (SP) na primeira metade do século XX a partir das imposições realizadas pelas forças políticas e econômicas hegemônicas em vigor nos momentos das anexações das terras agrícolas pelos circuitos espaciais de produção cafeeiro, algodoeiro e pecuário.

\section{Palavras-chave:}

caingangue; café; algodão; pecuária; região de Araçatuba (SP).

\section{Abstract:}

This work presents the history of occupation of the regional geographic space of Araçatuba (SP) in the first half of the twentieth century from the impositions carried by the political and economic forces existing in the moments of annexation of the regional lands for the space's circuits for the production of coffee, cotton and livestock.

\section{Keywords:}

caingangue, coffee, cotton, livestock; region of Araçatuba (SP).

\section{Introdução}

Analisando a região de Araçatuba e vislumbrando sua formação sócioespacial no início do século $X X$, encontramos - antes da expansão da lógica capitalista de propriedade, uso e gestão das terras localizadas no Oeste Paulista - os indígenas caingangues como o grupo humano possuidor dos direcionamentos dessa porção territorial. Até o início do século $\mathrm{XX}$, em uma relação de equilíbrio com a natureza, os caingangues não desenvolviam mudanças acentuadas em suas terras. Tal processo de territorialidade significou que eles não construíram objetos-próteses no que hoje é a região de Araçatuba.
Embasados por Santos \& Silveira (2001), entendemos que o que se constituiu foi:

"... a imposição à natureza de um primeiro esboço de presença técnica, pois ritmos e regras humanas buscavam sobrepor-se às leis naturais. Todavia a natureza comandava, direta ou indiretamente, as ações humanas. A precariedade ou a pobreza das técnicas disponíveis constituía o corpo do homem como principal agente de transformação tanto na produção como no enfrentamento das distâncias, e ainda aqui a natureza triunfa e o homem se adapta. Era um período de acomodação ez morosidade na relação com o meio, pois permitia-se que a floresta voltasse a crescer durante algumas décadas, antes

*Titulação: Mestre em Geografia Humana - Institutição: Pesquisador Científico do Instituto de Economia Agrícola (IEA) da Secretaria da Agricultura e Abastecimento do Estado de São Paulo. 
do plantio recomeçar num mesmo lugar" (SANTOS \& SILVEIRA, 2001, p. 29).

Desde antes da chegada dos portugueses até o início do século $X X$, os caingangues mantiveram seus domínios no que hoje é o extremo oeste paulista. No século XVI, segundo Sérgio Buarque de Holanda (1994)

"A permanência de caminhos numerosos que da vila de São Paulo conduziam, ora às minas gerais, ora ao sul, onde se estabeleceriam as primeiras reduções de guaranis, parece ter fixado, muito mais do que o rio Tietê, as direções iniciais da expansão bandeirante. $O$ valor dos rios estava, aparentemente, menos em servirem de vias de comunicação do que de meios de orientação" (HOLANDA, 1994, p. 34).

Já no século XVII, com a especulação de haver ouro no Mato Grosso, o Tietê se tornou rota de travessia. Nesse contato com os paulistas, os caingangues resistiram às bandeiras (monções) e às tentativas oficiais de colônias militares, como as de Avanhadava e Itapura no Tietê. O baixo Tietê apresentava índice de grande insalubridade e mais de uma vez correntes povoadoras tiveram de recuar em suas tentativas de se estabelecerem em tais áreas. Segundo Mussolini (1946), os caingangues "... não pertenciam aos grupos dos guaranis e habitavam principalmente os estados de São Paulo, Paraná, Santa Catarina e Rio Grande do Sul (...) Tratam-se de hábeis caçadores e também eram nômades" (MUSSOLINI, 1946, p. 24).

$$
\text { Manfredi Neto diz que }
$$

"... habitavam em cabanas cobertas de folhas de palmeiras, nunca fazendo divisões internas. (...) Criavam galinhas, domesticavam animais silvestres, tendo o cão como predileto. Viviam sem armamento sofisticado, com grandes arcos de pontas freqüentemente revestidos de ferro; colhiam o mel selvagem, cortavam palmito cuja medula consumiam, utilizavam fibras vegetais para tecer e fabricar cestas; as culturas de feijão, abóbora e milho eram as mais comuns: sua cultura era feita em terrenos incendiados e não se sabe quanto tempo permaneciam em cada local, pois o nomadismo era acentuado entre eles" (MANFREDI NETO, 1995, p. 28).

Foto 1: Contato Negociador dos Índios Caingangues com Representante doCapital Cafeeiro

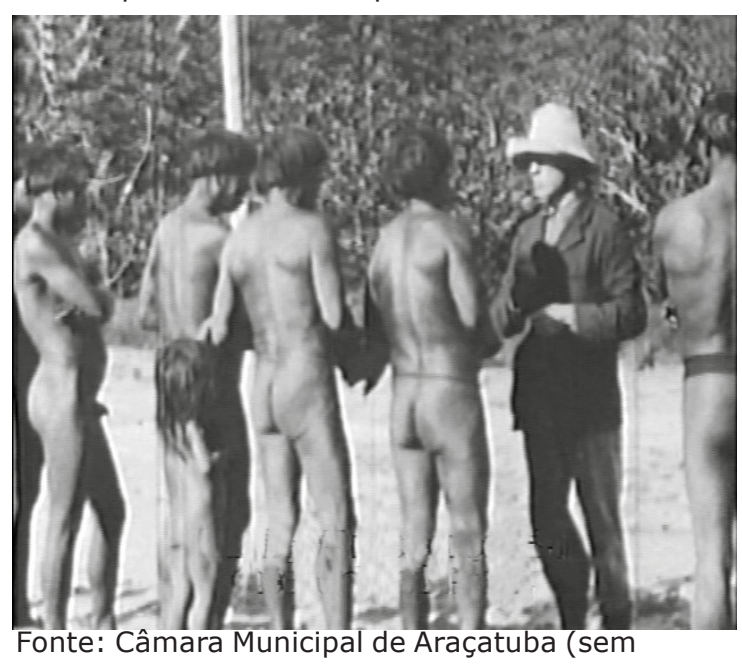

data).

Mas com a expansão da lógica capitalista de propriedade da terra, essas terras indígenas foram ocupadas e os caingangues foram praticamente dizimados. Desde meados do século XIX, os conflitos com os invasores paulistas se intensificaram. Ofendidos com a ocupação de suas terras nas proximidades do atual município de Bauru, os caingangues praticaram depredações e assassinaram dezenas de pessoas (Falleiros, 1999). Devido a essa resistência, findou-se o século e os interessados na posse das terras não conseguiram adentrar e anexar o Oeste com a pretendente introdução da monocultura cafeeira. A partir do ano de 1901, a luta se torna mais violenta. Em 1904, com o lançamento do decreto de concessão de construção de uma ferrovia de ligação ao Mato Grosso a partir de Bauru, a caça aos caingangues e a limpeza do futuro caminho dos trilhos se inicia de forma rápida e sanguinária.

\section{Fundamentação Teórico-Metodológica}

Embasados teoricamente nos escritos de Milton Santos, - em suas principais obras 
Formação sócioespacial da região de

Araçatuba na primeira metade do século XX, pp. 125 - 150

relacionadas a uma teoria e a um método da ciência geográfica - a discussão deste trabalho se dá pelo objeto da ciência geográfica: o espaço geográfico (Santos, 1978;1988;1994; 1994b; 2000; 2002; 2002b).

Assim, entende-se por espaço geográfico a parte da natureza modificada pelo trabalho humano durante o processo histórico. Dessa maneira, o espaço geográfico se caracteriza pelo trabalho humano materializado na superfície da Terra e em sua órbita ${ }^{1}$. Temo-lo como a união do trabalho morto, realizado no passado histórico (por todos os processos de produção precedentes, incluindo as antigas organizações do atual) com o trabalho vivo, esse último realizado no presente período histórico (pela específica organização do processo de produção vigente). Dessa forma, o espaço geográfico é perceptível no cotidiano como um conjunto de sistemas de objetos ${ }^{2}$ e sistemas de ações ${ }^{3}$ (Santos, 1994; 2002).

Na materialização de seu trabalho no espaço geográfico, a humanidade sempre desenvolveu técnicas facilitadoras para a execução de seus objetivos.

"Técnicas agrícolas, industriais, comerciais, culturais, políticas, de difusão da informação, dos transportes, das comunicações, da distribuição, etc; técnicas aparentes ou não em uma paisagem, são uns dos dados explicativos do espaço geográfico" (SANTOS, 1994, p. 61).

Tendo a técnica como instrumento intermediário das relações entre os seres humanos em humanos e entre esses e a natureza, no começo da história se imagina que havia técnicas na mesma proporção que agrupamentos humanos ${ }^{4}$. Com a passagem do tempo, as relações entre os grupos possibilitaram a expansão de técnicas dominantes e a extinção (ou limitação) de técnicas "menos eficientes". No presente período, denominado de período técnico-científico-informacional, com a expansão das empresas centrais do sistema capitalista a todos continentes do mundo, prenuncia-se com o atual processo de globalização, a unicidade das técnicas, em cada setor das atividades produtivas, em contexto mundial. Dessa maneira, sendo a Geografia a ciência que analisa a objetividade das relações sociais no espaço geográfico, vê-se a técnica como o melhor instrumento analítico dessa relação (Santos, 1994; 2002). Os sistemas técnicos transportam uma história, cada uma representando uma época.

Com a expansão do capitalismo pelo globo terrestre, os objetos geográficos predominantes tendem a ser os mesmos em toda parte, formando sistemas de objetos hegemônicos, surgidos para atender as necessidades das ações hegemônicas. Nesse processo de ampliação necessário para a reprodução do sistema capitalista o espaço se redefine como um conjunto indissociável no qual os sistemas de objetos são cada vez mais artificiais e os sistemas de ações são, cada vez mais, tendentes a fins estranhos ao lugar. (Santos, 1994; 2002). Seguindo essa concepção, compreendese que o lugar ou a região não é parte e o mundo o todo. A região não é um fragmento, é a própria totalidade em movimento que, através dos eventos, se afirma e se nega, caracterizando um subespaço do espaço global. A região é o outro da totalidade, transformando-se numa totalidade parcial, estando ligado às outras totalidades parciais, via totalidade global (SILVEIRA, 1997). A totalidade se funcionaliza no evento. Essa função é, de início, limitada num lugar, no qual o evento se materializa. Mas, em seqüência, o lugar fica total, porque na essência - e não na sua aparência - ele tem as conexões via totalidade com todos os outros lugares: "consideramos que no lugar o todo se nega mas também se afirma cada vez mais, porque o lugar não é uma parte, é o todo mesmo concretado no local" (SILVEIRA, 1997, p. 205). Os lugares se tornam mundiais, ainda que cada vez mais diferentes entre eles, e formam uma totalidade concreta, empírica. As funções dos lugares vão empiricizando a trama dos eventos que é a totalidade (Santos, 2002). Assim, a definição do papel que a região e cidade pólo (cidade média) estabelece enquanto totalidade parcial do mundo em movimento deve respeitar muito mais os critérios qualitativos e relacionais dados na sua situação funcional dentro da divisão territorial do trabalho do que as 
proporcionalidades engessadas dos elementos estatísticos (Sposito, 2001).

Assim, diante da ampliação da divisão internacional do trabalho do sistema capitalista, regiões e localidades mudam suas tessituras periodicamente, anexando em seus espaços geográficos conteúdos técnicos renovados por capitais forâneos sob a tutela da elite rentista regional. Nessas reconfigurações cada vez mais globalizadas, a administração política do território vivido pelas populações regionais que constroem com suas mãos a geografia de seus lugares escapa de suas próprias decisões.

Seguindo esses paradigmas, este trabalho tem como objetivo desvendar as funcionalidades da Região de Araçatuba e a ligação que ela passou a apreender e realizar junto ao país e ao mundo, partindo de uma abordagem histórico-espacial para a primeira metade do século XX. Pretende-se compreender alguns dos elos produtivos (econômicos) e políticos que a porção territorial estudada, enquanto totalidade parcial manteve e mantêm com outras totalidades parciais via Totalidade Mundo durante o processo de sua ocupação. Como Araçatuba e seu entorno se adequaram à integração funcional e territorial das redes dos circuitos produtivos globalizados de produção que se implantaram em seu espaço geográfico - café, algodão, pecuária de corte -, tornando-o, nos momentos de sua formação sócioespacial, especializado na realização de parte do processo de seus circuitos espaciais de produção.

Mapa 1: Atual Região Administrativa de Araçatuba (SP)

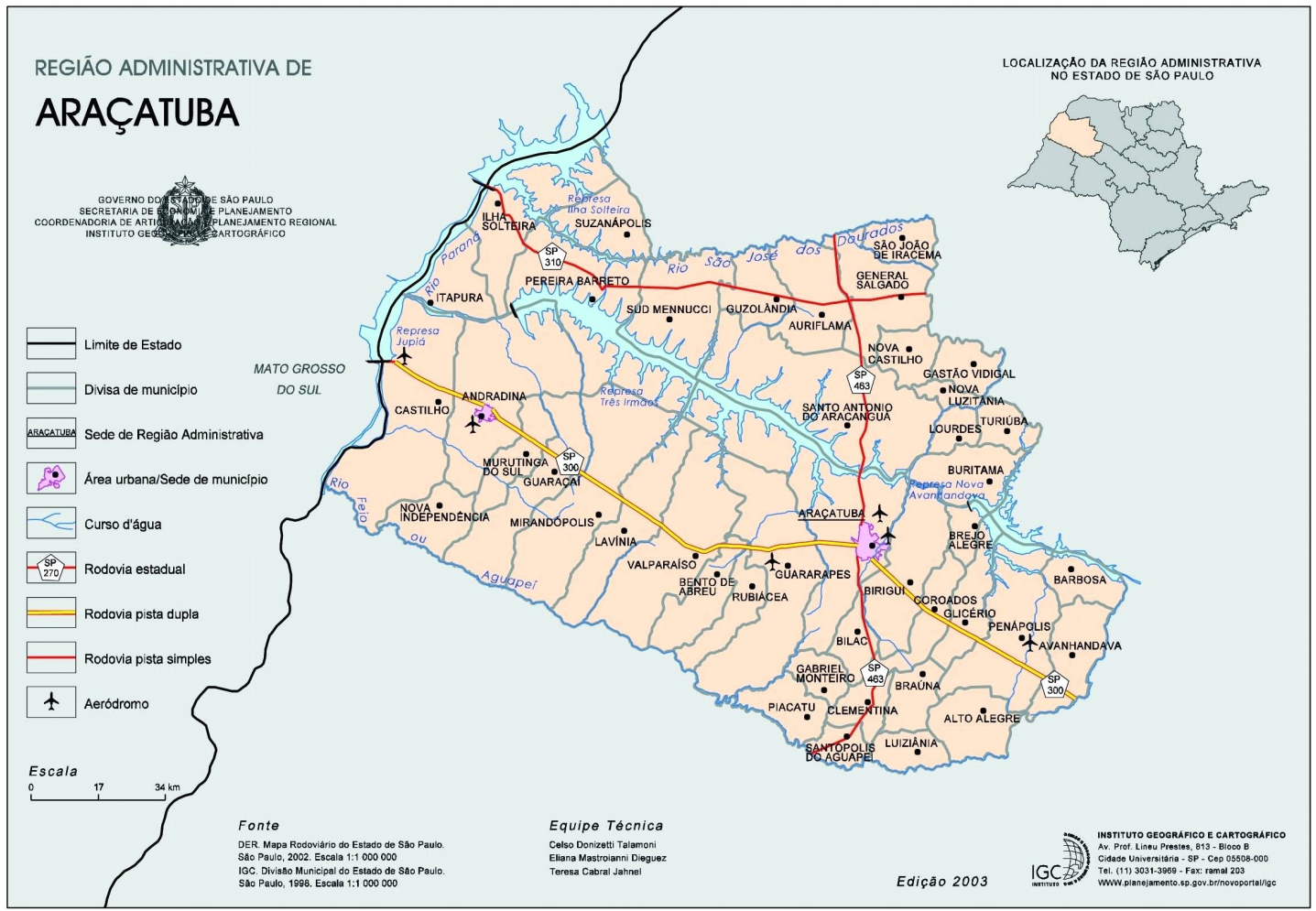

Fonte: Instituto Geográfico e Cartográfico (IGC, 2003). 
Formação sócioespacial da região de

\section{A Mecanização do Espaço Geográfico Paulista e a Cultura Cafeeira}

A fixação de objetos técnicos instaladores de novas funções ao território do Oeste Paulista está associada a um processo de transformações recorrentes às escalas estadual, nacional e mundial. Assim, a dizimação dos caingangues é parte de um desencadear de conquistas territoriais impresso pelo sistema capitalista no Brasil desde sua fase comercial. Dessa forma, para se apreender o significado da instalação de um meio técnico sobre o "sertão desconhecido" paulista, analisar-se-á, primeiramente, o desenrolar da formação sócioespacial brasileira no momento da expansão da cultura cafeeira.

A criação do Brasil e a colocação descontínua em seu território de meios técnicos (mecanização do território) provêm do processo de construção do capitalismo comercial em grande escala mundial. Estabelecidos em função da demanda do mercado externo, os sucessivos meios técnicos instaurados como zonas econômicas no território nacional, percorreram os períodos manufatureiro (1620-1750), da Revolução Industrial (1750-1870) e industrial (1870-1945), como um conjunto de 'penínsulas' da Europa (Santos \& Silveira, 2001). Essas regiões mantinham uma relação primordial com o estrangeiro e quase nenhuma entre si. Daí o porquê de Santos \& Silveira (2001) falarem do território brasileiro nesse período como um arquipélago.

A atividade da cana-de-açúcar (Zona da Mata Nordestina), aurífera (Minas Gerais, Goiás, Mato Grosso), do cacau (Bahia), da borracha (Amazônia) e cafeeira (São Paulo), mesmo tendo criado em suas regiões famílias e gerações de cidades, não construíram entre elas nenhum tipo de integração. A ausência dessa rede nacional de comunicação e circulação caracteriza esse momento territorial ou tempo espacial brasileiro como o "período da mecanização incompleta" (Santos \& Silveira, 2001).

Somente por volta de 1850, preocupações referentes ao isolamento do interior brasileiro levaram o governo imperial a começar a programar um plano de conexões entre as regiões. Relacionado a esse processo, Santos \& Silveira (2001) comentam que "Os portos, lugar de solidariedade entre navios, rotas de navegação e zonas produtivas, as ferrovias, as primeiras estradas de rodagem e usinas de eletricidade permitiram a constituição dos primeiros sistemas de engenharia no território brasileiro" (SANTOS \& SILVEIRA, p. 33).

No que se refere ao Oeste (Mato Grosso), ocupado durante as bandeiras e monções, originou-se como grande promessa no período aurífero, mas decaiu no afastamento das culturas pastoril e da erva-mate. Influenciado de início por rotas nordestinas, a pecuária bovina mato-grossense entra o século XIX grandemente direcionada ao circuito econômico argentino, paraguaio e boliviano. Sendo os caminhos "construídos" (descobertos) limitados às rotas que a natureza oferecia, o desenvolvimento pastoril encontrou na fluidez dos cursos das águas da bacia platina o melhor percurso para a comercialização de suas mercadorias. Com a convergência dessa vazante fora de nossas fronteiras, "... fácil é concluir pela disparidade do balanço, posta em evidência, desde logo, a supremacia indiscutível e formal, da força notável que conduz para o sul, para as terras estrangeiras, numa atração fortíssima, o sistema constituído nessa zona" (SODRÉ, 1990, p. 146).

Enquanto no Brasil as ferrovias estavam limitadas há alguns trechos isolados no litoral e uma rede nacional dessas estradas não passava de estudos, a Argentina começava a construir a sua rede ferroviária (1857), principalmente direcionada ao norte do país, em "simultaneidade com a difusão das estradas de ferro em países como a Inglaterra (1825), França (1841) e Estados Unidos (1869)" (SILVEIRA, 1999, p. 48). Isso potencializou a influência externa sobre o território mato-grossense, acelerando o impasse sobre a hegemonia dos fluxos (fluviais e ferroviários) dessa região brasileira, fazendo eclodir a Guerra do Paraguai.

Após a vitória no conflito - década de 1870 -, intermediado pelos interesses econômicos britânicos, o governo brasileiro, em aliança com a elite cafeeira paulista, inicia a implementação 
do projeto integrativo entre a província de São Paulo, Minas Gerais, Mato Grosso e alguns países da América do Sul (Paraguai e Bolívia). É nesse contexto de integrações regionais e da expansão da demanda por terras para o plantio do café que acontece a ocupação - mecanização - das áreas sob domínio caingangue na atual região de Araçatuba.

\section{O Café, a Ferrovia e seus Atores Hegemônicos}

A industrialização nos países centrais do capitalismo e a modernização dos transportes (com navios e locomotivas movidos a vapor) permitiram (impuseram) uma aceleração no comércio à distância entre as regiões do mundo. Pelo advento da Inglaterra como potência mundial, uma nova geografia de relações se instaura no processo produtivo, de circulação, distribuição e consumo da sociedade mundial. Sua urbanização iniciada nesse período muda os conteúdos da divisão territorial do trabalho: o rápido desenvolvimento de sua indústria exige, ao mesmo tempo, novos mercados aos seus produtos e novos territórios para a produção de matériasprimas e alimentos necessários ao funcionamento desse sistema.

No ambiente dessas transformações, o ingresso do Brasil, e da província de São Paulo especificamente, no mercado mundial do café, é acelerado. Essa cultura, desde o primeiro quartel do século XIX, colocava-se em avanço no espaço geográfico paulista. Primeiramente no Vale do Paraíba, ela se estende para a Depressão Periférica Paulista (Campinas-Jundiaí), principal região produtora durante a segunda metade do século XIX. Seu avanço ao oeste rumo a uma ocupação do planalto paulista tinha limites operacionais relacionados aos custos do transporte do produto ao litoral, de onde ele era encaminhado ao mercado consumidor internacional.

Até esse momento, a principal técnica de transporte entre o litoral e o interior, antes da construção das ferrovias, era constituída por numerosas tropas de muares e bovinos. Para a maior parte do país, o transporte em lombo de burro e puxado por bovinos atendia satisfatoriamente ao modesto volume do comércio exterior. A exceção a essa regra era a província de São Paulo, onde se produziam, no final do século XIX, excedentes exportáveis em torno de 500.000 arrobas de café que deixavam de ser vendidos ao exterior devido às deficiências de transporte. Isso correspondia a $25 \%$ da produção (Queiroz, 1999).

Unido ao discurso geopolítico de integração de São Paulo ao Mato Grosso, para superar esse gargalo e dinamizar com a fluidez necessária a expansão do circuito espacial de produção do café, surgiu o projeto de construção das ferrovias em direção ao Oeste.

\section{A Formatação da Espacialidade Capitalista na Província de São Paulo e na Região de Araçatuba}

Parceria dos fazendeiros e do poder público (que muitas vezes eram os mesmos atores) com financiadores internacionais possibilitou fundos de capitais para a construção das estradas de ferro ${ }^{5}$. Formada "por uma sociedade de ricos fazendeiros, que tirava sua força de sua dupla origem, rural e mercantil ao mesmo tempo" (MONBEIG, [1952] 1998, p. 97), a classe dirigente paulista, enquanto atora hegemônica do processo de anexação do oeste paulista ao circuito capitalista de produção, cria as sociedades ferroviárias ao redor de 1870 . Na continuidade do raciocínio, Monbeig ([1952] 1998) diz que

"... quando se pôs em movimento o avanço paulista (...), encabeçava-o uma classe de grandes fazendeiros, que ao mesmo tempo dirigia importantes sociedades bancárias e ferroviárias, bem como detinha postos na administração pública (...) Até a década de 1930, foram os grandes fazendeiros, de algum modo, os dirigentes de São Paulo. Confundia-se o interesse coletivo com o seu interesse de classe. Esse fato sociológico liga-se à geografia do movimento pioneiro. Os problemas de mão-deobra e, conseqüentemente, o povoamento, os das vias de comunicação, os dos preços foram considerados e tratados acima de tudo, em função 
Formação sócioespacial da região de

Araçatuba na primeira metade do século XX, pp. 125 - 150

dos interesses dos fazendeiros" (MONBEIG ([1952] 1998, p. 139-140).

As famílias Toledo Piza e Almeida Prado são exemplos desse grupo que concentrava atuação na atividade agrícola, ferroviária, bancária e principalmente, de interlocução com o capital internacional financiador da ocupação do oeste paulista (Monbeig ([1952] 1998). São essas sociedades que, na anexação de novas áreas requeridas ao abastecimento do centro do sistema, mecanizaram o espaço geográfico paulista mediante a instalação dos objetospróteses que são as ferrovias e a cadeia produtiva do café. Uma nova geografia dos fluxos significou a penetração e o conhecimento mais acelerados do interior, voltados aos interesses estrangeiros. A formatação dessa geografia é o que se verá mais adiante.

\section{As Ferrovias no Espaço Geográfico Paulista}

A década de 1870 foi um divisor de águas na modernização do espaço geográfico paulista. É nesse momento histórico que se criaram as possibilidades para que esse fragmento do território nacional se tornasse palco dos imperativos da divisão internacional do trabalho, começando a receber inovações garantidoras desse pertencimento.

Assim, as sociedades ferroviárias, São Paulo Railway Company, Companhias Sorocabana, Mogiana e Noroeste do Brasil, ligando lugares antes isolados entre si, surgiram dando fluidez às ações no espaço geográfico, como máquinas sugadoras de café das regiões especializadas no produto até aos portos e ao mundo 6 .

Retratando o histórico dessas companhias ferroviárias, aprofundando a análise na Noroeste do Brasil7, têm-se:

- São Paulo Railway Company: A São Paulo Railway Company (Estrada de Ferro SantosJundiaí), ferrovia pioneira de escoamento do café, foi construída e inaugurada em 1867 com capitais ingleses. Na expansão das áreas de cafeicultura, em 1868, um grupo de fazendeiros resolve criar a Companhia Paulista de Estradas de Ferro, ligando de início Jundiaí a Campinas e depois se prolongando até Bauru (Cruz, 2007).

- Companhia Sorocabana: A Companhia Sorocabana, iniciada em 1872, era formada por um grupo de dissidentes do consórcio que comporia a Companhia Ituana no mesmo ano. A primeira ligaria São Paulo a Ipanema, a segunda, Itu a Jundiaí. O primeiro trecho da Sorocabana, com $120 \mathrm{Km}$ de extensão, foi inaugurado em julho de 1875, e três anos depois estendeu suas linhas para as cidades de Tietê, Tatuí, Itapetininga e Botucatu. As linhas da Companhia Ituana chegaram em Piracicaba em 1877, promovendo uma integração com o transporte fluvial até o porto de Lençóis. Em 1892, as duas companhias se fundiram formando a Companhia União Sorocabana, a maior rede ferroviária do estado com $820 \mathrm{Km}$ de extensão. A partir da fusão, novas linhas foram construídas, principalmente rumo ao ramal Bauru. De 1907 a 1919, depois de uma crise que a passou ao controle estatal, foi arrendada a um consórcio franco-americano, que atingiu Presidente Prudente até às margens do Paraná. Contudo, o maior feito da Sorocabana foi a quebra do monopólio da São Paulo Railway, com a ligação ao Porto de Santos via Mairinque (Araújo Neto, 2006).

- Companhia Mogiana: Em 1872, um outro grupo de fazendeiros funda a Companhia Mogiana de Estradas de Ferro, com o intuito de propiciar o escoamento do café de uma das regiões mais produtivas da província no momento, a região de Mogi-Mirim e Amparo. Nas próximas décadas a companhia estendeu seus trilhos para Minas Gerais e para a região de Ribeirão Preto, sendo esta última a de maior destaque na produção cafeeira do começo do século XX. Para essa expansão, o empréstimo de capitais ingleses foi fundamental (Saes, 1981).

\section{Companhia Estrada de Ferro Noroeste do Brasil (E.F.N.O.B)}

Essa integração da elite nacional - a partir da motivação geopolítica de aproximação do Mato Grosso e de países vizinhos (como Paraguai e Bolívia) ao circuito econômico brasileiro (Travassos, 1938) - com as elites internacionais, 
através de parcerias nos empreendimentos da cadeia produtiva do café, confirma a anexação territorial do interior paulista pela lógica do capitalismo global. Assim, as ferrovias SantosJundiaí, Sorocabana, Mogiana e Noroeste do Brasil são exemplos de aberturas infraestruturais colocadas à serviço dos interesses geopolíticos do governo imperial e dessa expansão territorial da cultura cafeeira ao oeste paulista.Com Furtado (1959)compreende-se de que o aumento da produção demandado pelo consumo no mercado internacional do café era obtido de forma extensiva, com a expansão das áreas de plantio. Assim, sendo o café o produto do momento e o oeste paulista o espaço 'vazio' - em contigüidade - mais propício ao avanço da cultura, os dirigentes políticos e econômicos trataram de resolver o principal problema surgido para a integração dessas novas áreas: reforçar os interesses geopolíticos existentes ligando uma infraestrutura de transporte possibilitadora de custos de produção factíveis ao escoamento da mercadoria ao litoral.

Dessa forma, enquanto a Paulista, a Mogiana e a Sorocabana buscaram as regiões já povoadas e com produção substancial de café, no intuito de resolver os problemas de seu escoamento ao litoral, a Noroeste do Brasil, ao ser construída, avançou por áreas quase 'despovoadas' do território do estado de São Paulo (Saes, 1981).

Foto 2: Primeira Estação Ferroviária (Um Vagão) em Araçatuba

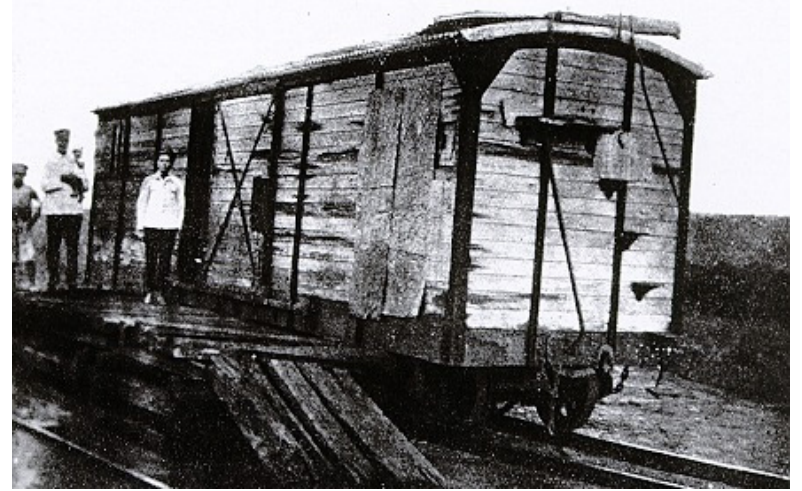

Fonte: Câmara Municipal de Araçatuba (sem data).
Foto 3: Segunda Estação Ferroviária em Araçatuba

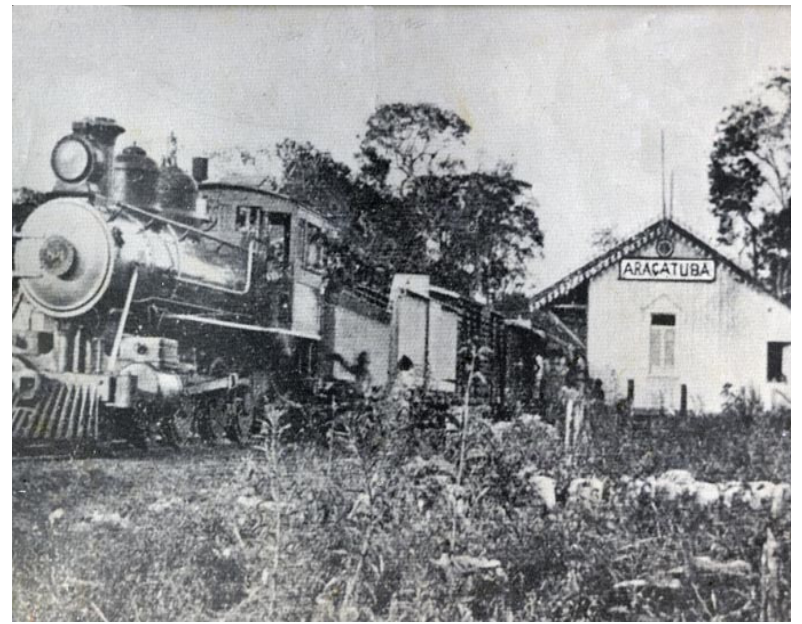

Fonte: Câmara Municipal de Araçatuba (sem data).

De capitais mistos, brasileiro e francobelga, com concessão de garantia de juros baixos pelo governo federal, a construção da Noroeste se iniciou em 1905. Terminados os estudos para a locação da linha férrea, a Companhia de Estradas de Ferro Noroeste do Brasil e a companhia empreiteira dos serviços mandaram para Bauru os primeiros engenheiros, técnicos e operários que se encarregariam da construção. Muitos morreram de várias moléstias (como a leishmaniose e a malária) e no confronto com os índios caingangues. Em 2 de dezembro de 1908, os trilhos chegavam ao quilômetro 281, onde futuramente seria fundada a cidade de Araçatuba.

\section{A Ocupação das Terras da Região de Araçatuba}

Mesmo antes das possibilidades técnicas dadas com o advento das estradas de ferro, a elite dirigente buscou alternativas oficiais de reconhecimento e anexação do oeste paulista. Mesmo pertencendo aos silvícolas caingangues, através da Lei de Terras de 1850, as terras da região foram normatizadas como devolutas; propriedade do governo imperial do Brasil. 
Formação sócioespacial da região de

Araçatuba na primeira metade do século XX, pp. 125 - 150

Cavenagui (2004), em um excelente trabalho sobre o uso político da fotografia e da cartografia no espaço geográfico paulista de 1850 a 1910, mostra como, mesmo antes da ocupação, operou-se a legitimação da posse dos 'terrenos desconhecidos' no planalto paulista. São apresentadas produções cartográficas da província de São Paulo, onde os territórios indígenas são incorporados sob a administração da elite política e econômica paulista.

Tendo cada porção territorial o seu valor, o oeste paulista, mesmo inutilizado economicamente até o final do século XIX pelo sistema econômico hegemônico em expansão, através dessa cartografia citada, passa a ser colocado como uma reserva de valor a ser explorada nos anos vindouros. Para Magnoli (1996), essa produção cartográfica serviu para reforçar o caráter de devolutas das terras 'desocupadas' do Brasil e legalizadas com a Lei de Terras de $1850^{8}$.

Após a Lei de Terras, com o 'poder público' tendo o controle dessas terras 'desocupadas' rumo a uma regularização fundiária capitalista, as terras passam, em sua grande maioria, a ser vendidas às companhias de colonização, que por sua vez, as revendiam em condições muito lucrativas.

A Lei de Terras deu um prazo de alguns anos para a legalização de propriedades, o que também incentivou posseiros a atuarem no 'sertão desconhecido' de São Paulo (Cavenaghi, 2004). Com isso, a partir de 1850 , devido ao declínio da produção aurífera e a obrigatoriedade do alistamento militar para a Guerra do Paraguai, muitos mineiros, encontrando possibilidades de enriquecimento, começaram a ocupar as terras do oeste paulista (Queiroz, 1999).

Antes desse período, a 'boca do sertão' para o oeste era Botucatu. Com essa corrida pela legalização, foram registradas posses de terras e se deu o surgimento de povoações em Franca, Bauru e na região do rio Paranapanema. Muitos indígenas dessas regiões - principalmente de Bauru - se deslocaram para o extremo oeste paulista, entre os rios Aguapeí e Tietê, onde hoje se localiza Araçatuba (Ghirardello, 2000).
Até 1880 , a ocupação de terras existente de Botucatu a Bauru foi subordinada à população local, onde a produção agrícola em sua maioria era destinada à subsistência. Somente o excedente - carne de porco, principalmente - era comercializado nas feiras de Lençóis Paulista, Botucatu e Sorocaba (Ghirardello, 2000). Praticando uma agricultura de roça antiquada e no limite do mercado - sendo quase a totalidade da produção direcionada para o próprio consumo -, os mineiros ocupadores das terras entre Bauru e Botucatu exerceram a função histórica de abrir os "terrenos desconhecidos" para a futura instalação das atividades capitalistas.

No final da década de 1880 , o povoado de Bauru passa a crescer rapidamente devido à abertura em suas proximidades de grandes lavouras de café 9 . Com o aumento da demanda desse produto no mercado internacional, os grandes cafeicultores viram no oeste paulista a opção de reverterem seu capital ${ }^{10}$ com a propriedade de terras baratas e mesmo gratuitas (na ocupação e falsificação de posse de terras devolutas). Assim, de Bauru em direção ao extremo oeste, marginando a linha ferroviária, a ocupação das terras foi realizada de maneira diferente da ocorrida entre Botucatu e Bauru pelos mineiros. No ato de estender a fronteira de ocupação "civilizatória" à oeste, introduziu-se diretamente, sem intermediação, os tentáculos (objetos) técnicos distintivos daquele momento de modernidade do capital: a ferrovia e o circuito espacial do café. Diferente das variáveis conjugadas no gênero de vida mineiro, a produção do espaço geográfico na Noroeste Paulista impôs normatizações ao uso das terras da fronteira estendida formuladas por atores estranhos ao seu cotidiano até então configurado pela cultura, técnicas e normas caingangues.

Esse processo de anexação da Noroeste Paulista ocorreu em duas etapas distintas: de Bauru à Promissão, com um caráter mais familiar; e de Promissão à Andradina, com um estilo mais empresarial. Findando essa primeira etapa, em 27 de setembro de 1906 foi inaugurado o primeiro trecho de Bauru rumo ao extremo oeste paulista. Esse trecho já possuía uma recente ocupação rural, feita por grandes 
famílias da elite econômica paulista, que se adiantaram aos trilhos: os Rodrigues Alves e os Toledo Piza (Falleiros, 1999).

Como as vilas (futuras cidades) nasceram à beira das estações, as plantações surgiram às margens da estrada de ferro. Em cada estação se "nomeava" um agente imobiliário, o qual intitulava fundador. À medida que a influência de novos moradores exigia, das ruas principais se prolongavam novos quarteirões junto com praças, avenidas e outros logradouros públicos (Ghirardello, 2000).

Era da cidade que se executavam diretamente as ordens longínquas de como deveria funcionar o gerenciamento da lavoura cafeeira. Doadas ou vendidas à Câmara Municipal da cidade de Bauru - que fora elevada no fim dessa primeira década à comarca jurisdicional abrangendo toda a Noroeste - as áreas circundantes das estações de Pirajuí, Avaí e Lins surgiram como vilas, distritos de paz de Bauru. Cafelândia e Promissão foram retalhadas pelos próprios proprietários, que dividiram as terras em datas e as colocaram à venda (Ghirardello, 2000).

De Promissão à Araçatuba, a ocupação aconteceu de forma menos familiar e mais empresarial, respaldada por capitais internacionais (Martins \& Ramos, 1961). A figura do coronel Manoel Bento da Cruz no retalhamento do que se constituirá a Noroeste Paulista, foi de fundamental importância. Como enviado de agentes públicos e privados de São Paulo e Rio de Janeiro - capitais da província e da federação respectivamente - em 1905 já está na região que seria atravessada pela estrada de ferro.

Em um primeiro momento, Bento da Cruz, advogado, apresenta-se como defensor dos direitos de propriedade para as famílias dos antigos posseiros - mineiros - que ocuparam a região no início do século XIX nas proximidades da colônia militar de Avanhandava ${ }^{11}$.

"(...)Longe de ser uma personalidade singular, Manoel Bento da Cruz representava bem a moral dos primeiros anos republicanos, a ética dos novos tempos (...) Dentro desses paradigmas, Manoel Bento da Cruz será como nenhum outro, na Zona Noroeste, um representante dos novos tempos de liberalismo econômico" (GHIRARDELLO, 2000, p. 78) ${ }^{12}$.

Manifestando bem o espírito da época, para introduzir as inovações do período na área, o extermínio da quase totalidade das dezenas de milhares dos resistentes índios caingangues era a próxima tarefa a se executar. Com o início da construção da estrada de ferro e a conseqüente valorização das terras, as tentativas de penetração e de apossamento se multiplicaram. Foram organizadas verdadeiras expedições de combate aos índios - sendo a carabina Winchester a principal técnica de guerra dos brancos - que não puderam resistir com suas flechas e emboscadas. Foram completamente vencidos e obrigados a aceitar em negociação intermediada pelo Serviço de Proteção ao Índio (SPI) as reservas e os aldeamentos que lhes foram oferecidos - Icatu em Braúna e Capitão Kenkrá e Vanuire em Tupã (Falleiros, 1999).

Foto 4: Clareira Aberta por Queimada para Instalação da Lavoura de Café

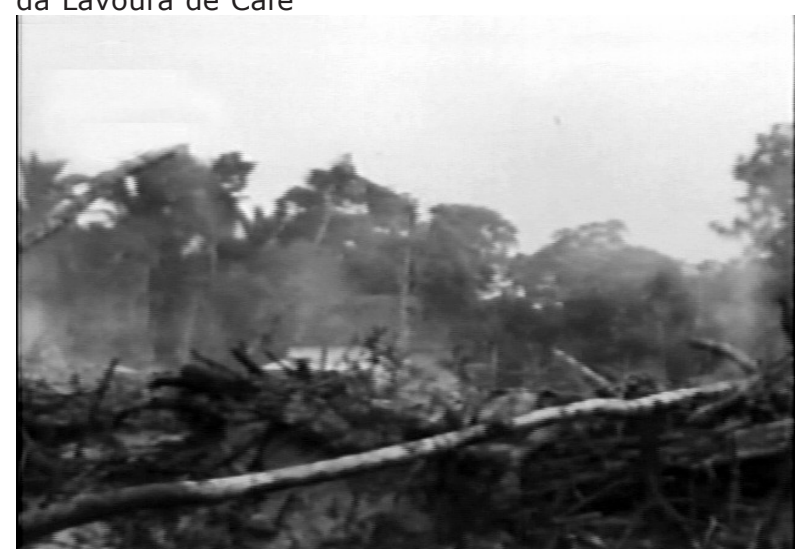

Fonte: Câmara Municipal de Araçatuba (sem data)

O fim do conflito e da carnificina em 1912 representou a liberdade da franca ocupação das terras pelos representantes do capital internacional, que anexando os sistemas de objetos e ações distintivos do plantio, armazenamento e comercialização do circuito produtivo do café, colocou a região Noroeste Paulista como totalidade parcial do sistema econômico global em expansão: 
Formação sócioespacial da região de

Araçatuba na primeira metade do século XX, pp. 125 - 150

"Livre dos indígenas era possível adentrar mais em direção aos rios Aguapeí/Feio e Tietê e a ocupação poderia se descolar dos trilhos oferecendo terras mais baratas ainda. Para isso, bastavam ser criadas estradas vicinais, perpendicularmente aos trilhos, a partir das estações da C.E.F.N.O.B. (...) A escala do parcelamento agora seria outra, de cunho francamente empresarial, e em 12 de outubro de 1912 é criada a 'The San Paulo Land, Lumber \& Colonization Company' - Companhia de Terras, Madeiras e Colonização São Paulo. São sócios majoritários na empresa o coronel Manoel Bento da Cruz, Presciliano Pinto de Oliveira, o inglês James Mellor e o escocês Robert Clark. O capital da sociedade, em boa parte inglês, foi instituído com o valor de 800:000\$000, divididos por 8.000 ações integralizadas" (GHIRARDELLO, 2000, p. 84).

Foto 5: Estrada Aberta no Meio da Mata do Planalto Ocidental Paulista

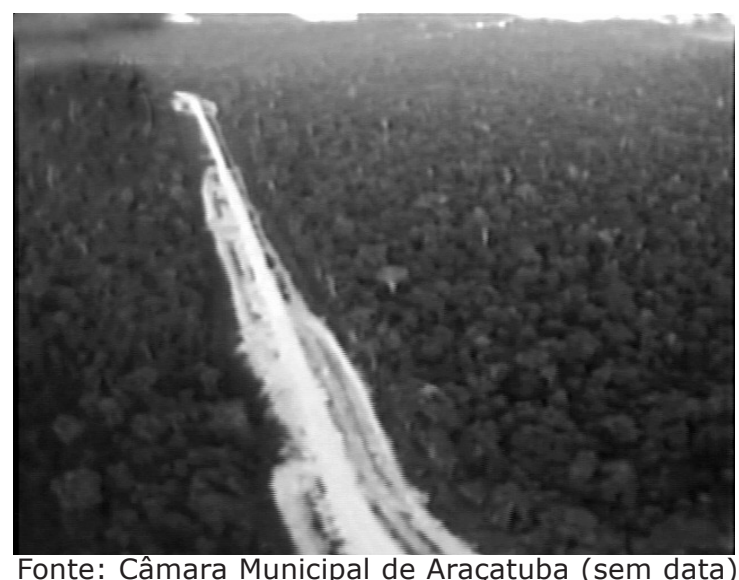

A Companhia adquiriu a organização de terras reconhecidas pelo governo e fez o levantamento geral de uma área de $60 \mathrm{mil}$ alqueires de matas virgens situadas entre as vertentes do rio Feio e do rio Tietê. Em 10 anos, já em 1922, havia se dividido em lotes 38.434 alqueires distribuídos à 2.032 sitiantes nacionais, portugueses, espanhóis, japoneses e italianos (Martins \& Ramos, 1961) ${ }^{13}$. Abriu a Companhia de Terras, Madeiras e Colonização São Paulo 700 quilômetros de estradas de penetração entre a estrada de ferro e o Rio Feio. Fundou vilas onde foram levantadas as lojas de comércio para abastecimento dos sitiantes e os centros de venda e beneficiamento do café. Tudo isso possibilitou uma valorização enorme nos preços das terras da região.

Seguindo mais ao oeste, em direção às barrancas do Rio Paraná, tivemos a ocupação de uma porção territorial da Noroeste que ficou conhecida como 'Variante'. Seguindo os trilhos rumo ao Mato Grosso, a Companhia de Estradas de Ferro, mesmo sob orientações e divergências decidiu realizar o traçado da ferrovia de Araçatuba até o rio Paraná às margens do rio Tietê e não mais pelo espigão como ocorrera até então. Sua construção foi feita entre 1908 e 1910 (Pinheiro \& Bodstein, 1997).

A insalubridade do terreno - com a morte de dezenas de trabalhadores da construção da ferrovia de malária e leishmaniose - e a péssima condição dos trilhos construídos com materiais de baixa qualidade levaram essa linha e a região que a circunda (Araçatuba-Itapura) ao abandono (Falleiros, 1999).

Os atritos políticos e jurídicos em relação à posse da terra de Araçatuba ao Mato Grosso - na chamada Fazenda Aguapeí - também adiou a ocupação em direção ao rio Paraná. Vislumbrando a valorização das propriedades com a extensão dos trilhos da Noroeste e a expansão do mercado consumidor do café no mundo, duas companhias de colonização se autoproclamaram donas das terras da Variante. Esse conflito ocorreu de 1910 a 1930, ficando Araçatuba ("Boca do Sertão"), durante a década de 1920, marcada pela violência entre esses dois grupos (Pinheiro \& Bodstein, 1997).

Com a passagem da penhora do "fruto pendente" e do "fruto colhido" no lugar da hipoteca imóvel como garantia de pagamento do capital de custeio emprestado junto aos bancos para a realização da produção, é o valor dessa produção que dá o preço da terra (Martins, 1996). Assim, durante esse período, com a subida do café no mercado mundial, as terras em litígio da 
fazenda Aguapeí aumentaram seu valor de 10 para 100.000 réis. Nesse processo, cada grupo ocupou parte da propriedade, derrubaram as matas, plantaram milhares de cafeeiros e construíram pastos para a criação de gado.

Como bem coloca Rego (1990),

"O importante, naquele momento, era, através da produção, assegurar a efetiva posse das terras. Tanto é assim que, mesmo toda essa área estando em litígio, (...), a terra estava sendo vendida a grandes e pequenos produtores e o café avançava no rumo leste-oeste, enquanto o gado avançava de oeste para leste" (REGO, 1990, p. 19) $)^{14}$

Devido a essa instabilidade econômica gerada pelo conflito, não saiu do papel até a década de 1930 a construção de uma linha de ferro entre Araçatuba e o Mato Grosso, ficando adiado o projeto de aceleração da integração do território nacional via essas duas regiões. Diferente do anterior, o novo traçado planejava cortar as terras em litígio pelo espigão divisor de águas entre o rio Feio e o rio Tietê.

Figura 1: Divisor de Águas entre os Rios Feio e Tietê

\section{O Tietê}

e seus afluentes

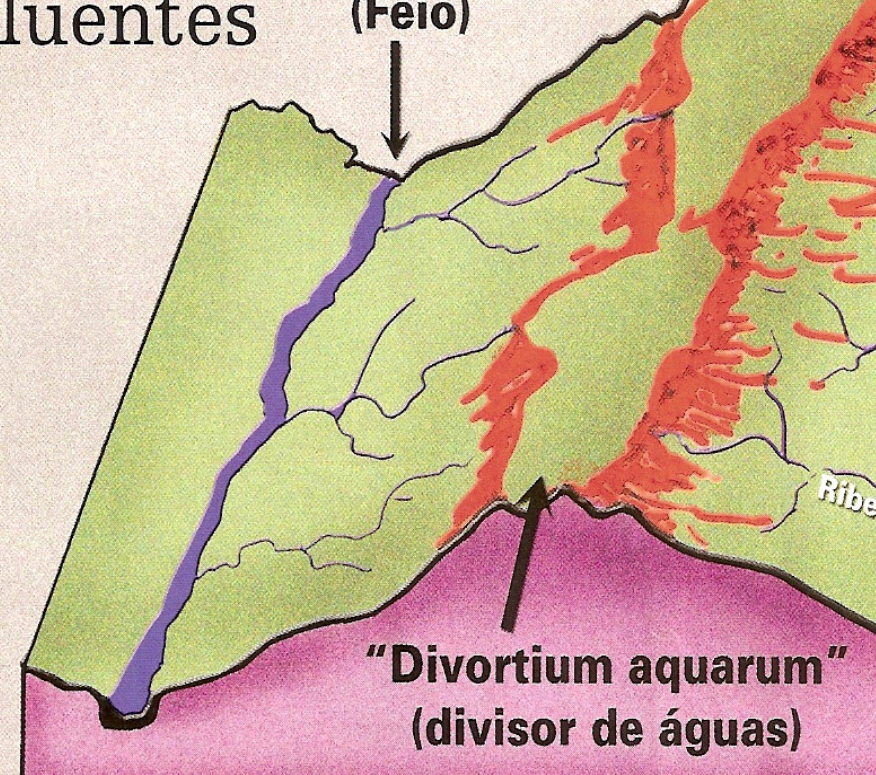

Rio Aguapeí 
Formação sócioespacial da região de

Araçatuba na primeira metade do século XX, pp. 125 - 150

Manoel Bento da Cruz também tomou parte no embate pela posse da fazenda Aguapeí. Financiado por capitais ingleses e banqueiros da capital paulista e federal, o coronel fundou uma companhia de colonização para a área, derrubou muitos hectares de mata, comercializou a madeira, plantou milhares de cafeeiros, abriu invernadas para engorda de gado e construiu a famosa Estrada Boiadeira, onde cobrava pedágio para quem nela entrava e saía (Pinheiro \& Bodstein, 1997). A balsa para travessia do rio Paraná - que passou a deslocar parte do gado de Mato Grosso e transformou os fundos de vale da Variante em locais de engorda rumo aos matadouros de Barretos e São Paulo - e a construção da primeira usina hidrelétrica na região foram também obras de Bento da Cruz (Rego, 1990).

Foto 6: Colheita de Café em Colônia Japonesa na Região de Araçatuba

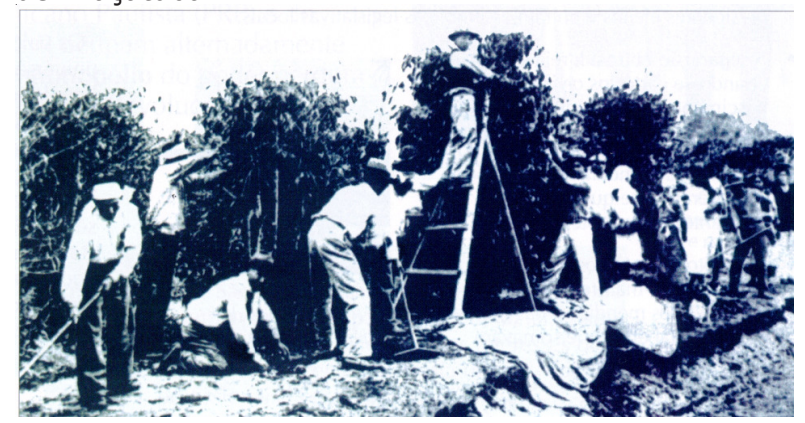

Fonte: Câmara Municipal de Araçatuba (sem data).

Em 1929, com a crise da economia mundial, diminuiu-se a demanda pelo café, caindo seu preço. Nesse rearranjo interno da economia brasileira, diminuíram os conflitos pelas terras da Aguapeí, que tiveram seus valores relativos em queda comparados ao período anterior. No decorrer da década de 1930, sai do papel a construção da linha Variante - que deu nome a essa porção territorial - com trajeto AraçatubaJupiá.

Como ocorreu desde Bauru, da beira das estações da Companhia de Estradas de Ferro Noroeste do Brasil (C.E.F.N.O.B) após Araçatuba surgiram povoados que logo se emanciparam: Guararapes, Valparaíso, Guaraçaí e Andradina.
Com a expansão da cultura do café em meados da década de 1920, a Zona Noroeste Paulista é vista como sonho de enriquecimento por pessoas de várias regiões do Brasil e do mundo. Falleiros (1999) mostra como milhares de nordestinos se deslocaram para a região para trabalhar na derrubada da floresta e construção da ferrovia, ali ficando por toda a vida. Sobre essa mobilidade de força de trabalho, Monbeig (1998) diz:

"Durante cinco anos, de 1926 a 1930, as zonas rurais do Estado de São Paulo receberam um contingente de 233.202 trabalhadores estrangeiros e nacionais que passaram pela Hospedaria dos Imigrantes (...) Os espigões onde o aumento dos cafezais havia sido mais acentuado, eram os maiores chamarizes: para lá foram 31,1\% dos imigrantes. A parte do leão coube à Noroeste que, sozinha, drenou mais do que 1/4 da imigração paulista $(26,6 \%)$, ou seja, 62.205 indivíduos. Alguns municípios concentraram pequenos exércitos de trabalhadores rurais, como foi o caso de Araçatuba, a mais ocidental, com 13.365 imigrantes". (MONBEIG ([1952] 1998, p. 193).

Configurando os sistemas de objetos e os sistemas de ações humanos da região, nas áreas urbanas se localizavam, além da estação ferroviária, a igreja, as casas de comércio, as casas bancárias, os armazéns de estocagem, as vendas de produtos alimentícios e de primeiras necessidades e as residências daqueles que trabalhavam na prestação desses serviços urbanos.

A grande maioria da população morava nas áreas rurais. Como o trato da lavoura necessitava de mão-de-obra o ano todo, cada grande proprietário dispunha em suas terras de uma pequena vilinha - a colônia - onde viviam os trabalhadores rurais (colonos), no característico regime de trabalho denominado colonato. Mesmo os pequenos e médios proprietários tinham suas residências no campo, o que fazia da Noroeste Paulista nesse primeiro momento, como em todo o interior do país, uma região pouco urbanizada. As cidades eram as localidades "nó" onde os representantes do capital financeiro nacional e internacional gerenciavam o escoamento das 
mercadorias e de toda riqueza produzida nas terras da região.

Foto 7: Panorâmica da Centralidade Surgida ao Redor de Estação Ferroviária na Região de Araçatuba

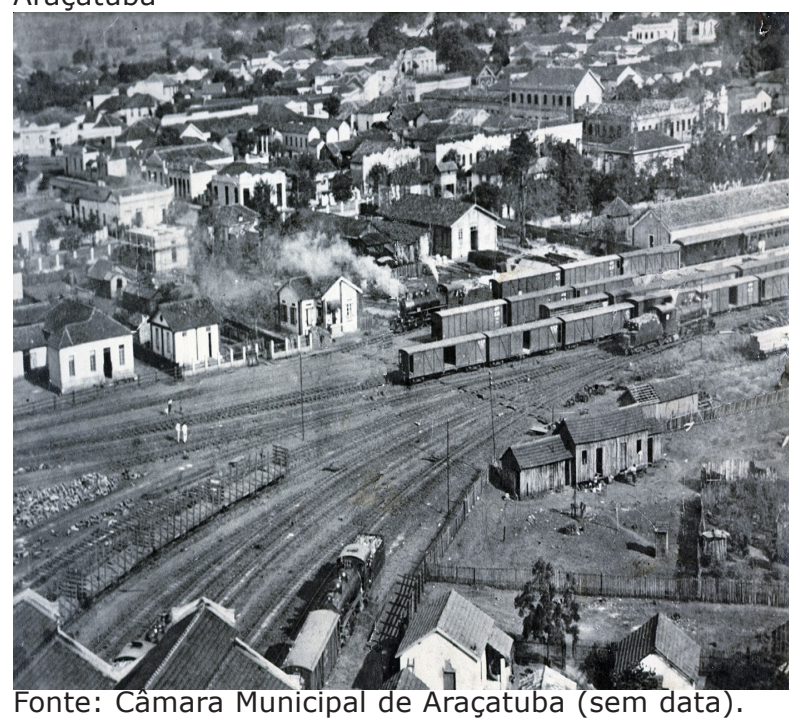

\section{O Circuito Produtivo Algodoeiro na Região de Araçatuba}

Como o quadro de predominância quase absoluto do café se abalou com a crise mundial do sistema capitalista em 1929, foi lançada a base do modelo de acumulação no Brasil para uma estrutura produtiva mais moderna, sedimentada na indústria.

Continuidade de um período transitório, a década de 1930 e início da de 1940 estabeleceu "um começo de integração nacional e um início da hegemonia de São Paulo, com o crescimento industrial do país e a formação de um esboço de mercado territorial localizado no Centro-Sul" (SANTOS \& SILVEIRA, 2001, p. 37). Portos e estradas de ferro possibilitaram a interligação criadora de uma rede brasileira de cidades. As cidades industriais passam a comandar os fluxos sobre o espaço regional onde elas estão localizadas, ou seja, efetiva-se uma nova hierarquia entre os lugares criada pela disseminação do sistema técnico industrial em pontos do território brasileiro. Centralizado no Rio de Janeiro e em São Paulo, será essa última cidade, a partir do sistema de engenharia em montagem desde o período do café, que controlará cada vez mais os fluxos de uma economia nacional em construção.

Este novo momento econômico se inicia com o governo de Getúlio Vargas, que representou as aspirações democráticas almejadas pela classe média urbana e pela burguesia industrial. Baseado em um forte intervencionismo, principalmente político nas províncias, o governo Vargas desencadeou uma visão integradora do território nacional pelas políticas públicas estatais. Novos trechos de ferrovias foram anexados ao território (como na Estrada de Ferro Vitória-Minas) e alguns trajetos interligados (no caso da EFNOB, o trecho paulista se interligou ao mato-grossense). Regiões de matérias-primas se aproximaram das novas áreas industriais. Com a criação do Conselho Nacional do Petróleo (1938), da Companhia Siderúrgica Nacional (1941) e da Companhia Vale do Rio Doce (1943) se institucionalizaram as bases para que o país se desenvolvesse, construindo internamente suas indústrias de bens de capitais.

Como parte dessas mudanças, no setor agrícola, a oligarquia agroexportadora brasileira perde espaço no novo reordenamento do poder político nacional ${ }^{15}$. Diante de pressões demandantes de reformas no eixo das ações de desenvolvimento do país, a agricultura passa a ter como principal papel ofertar alimentos às cidades industriais em crescimento. Analisando os planos de governo e suas políticas implementadas de 1930 até $1964^{16}$, Espírito Santo (2005) conclui que eles se limitaram em posicionar a agricultura com essas duas funções: abastecimento do mercado interno e exportação criadora de divisas.

Como exemplo de culturas agrícolas que exerceram essas funções, na Noroeste Paulista, com o declínio da cultura cafeeira após a crise do capitalismo em 1929, são o algodão e a pecuária extensiva que passam a fazer uso de grande parte do espaço geográfico dessa porção da província paulista ${ }^{17}$. Não acarretada somente pela demanda da indústria nacional, a expansão da cultura 
Formação sócioespacial da região de

Araçatuba na primeira metade do século XX, pp. 125 - 150

algodoeira em São Paulo se relacionou fortemente com o fim de sua atividade em alguns territórios estrangeiros, o que desequilibrou a oferta desse produto no mercado internacional. Assim, a crise de 1929 que iria lançar a cafeicultura em longo período de graves dificuldades, colocou os cafeicultores na contingência de tentar novas explorações que viessem compensar a perda de renda por eles sofrida. Dentre as diversas explorações agrícolas então ensaiadas, a do algodão era uma daquelas que melhores perspectivas apresentavam, devido ao seu alto preço no mercado internacional (MONBEIG ([1952] 1998).

\section{Novos Conteúdos do Circuito Algodoeiro}

Reordenando sua funcionalidade na divisão internacional e territorial do trabalho, a principal especialização nesse momento na atividade algodoeira das terras da Noroeste Paulista trouxe novos objetos e ações para a constituição do espaço geográfico regional. Do circuito algodoeiro, grandes indústrias de beneficiamento se instalaram, diferente das pequenas unidades que foram construídas para beneficiar o café. "A superestrutura capitalista está melhor organizada quando se trata da jovem cultura algodoeira, do que quando se relaciona com a tradicional cultura do café" (MONBEIG ([1952] 1998, p.301). Anderson Clayton, SANBRA, Indústrias Reunidas Francisco Matarazzo, Saab SA. e algumas Cooperativas - japonesas principalmente - construíram suas fábricas em quase todos os municípios da região de Araçatuba na época, concentrando-se num primeiro período nos municípios a leste, estendendo-se timidamente a partir de 1940 até à divisa com o Mato Grosso. Além de beneficiar o algodão, produziam óleo, tecidos e exportavam seus produtos em grande escala (REGO, 1990).

Capitais americanos, ingleses, japoneses e brasileiros foram investidos de forma substancial na produção do algodão (Monbeig ([1952] 1998), fazendo de seus detentores e aliados os atores hegemônicos desse novo momento da Noroeste Paulista ${ }^{18}$. Com a situação política inquietante no Sudão - colônia britânica , os ingleses e americanos inverteram seus investimentos no oeste paulista, sendo a Anderson Clayton e SANBRA as marcas representantes de seus capitais. As companhias colonizadoras japonesas agiram através de suas Cooperativas, promovendo a fixação de seus imigrantes nos loteamentos organizados em todo o oeste do estado de São Paulo (Noroeste e Sorocabana principalmente) $)^{19}$

Foto 8: Indústria Beneficiadora de Algodão SANBRA em Araçatuba (Anos 1930-1940)

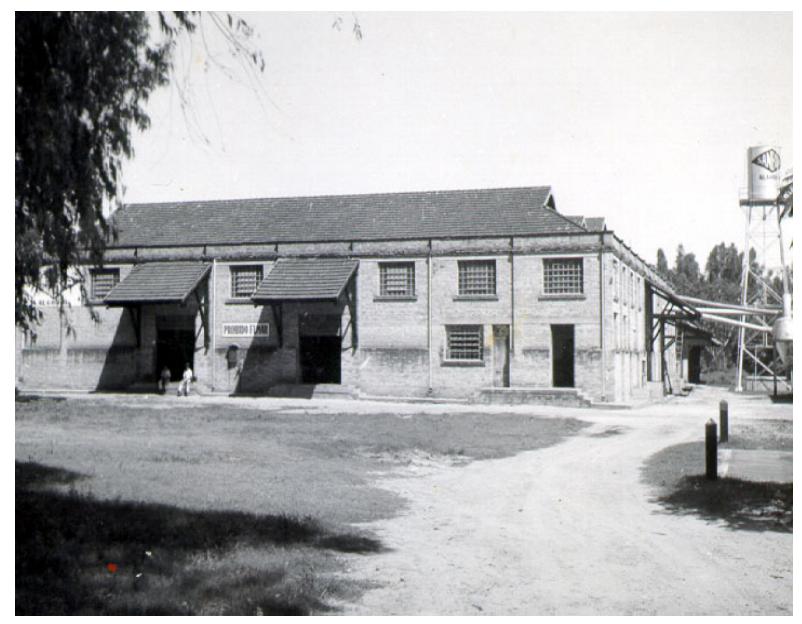

Fonte: Câmara Municipal de Araçatuba (sem data).

Essas empresas financiavam os pequenos produtores. Sem acesso ao crédito institucionalizado, esses lavradores acabavam se comprometendo a entregar sua produção a essas grandes companhias, mediante um adiantamento. A Carteira de Crédito Agrícola e Industrial (CREAI) do Banco do Brasil, criada em 1937, surgiu como a primeira forma de acesso ao crédito agrícola no país que começou a ser organizado de forma racional e em escala ampla. Contudo, não dispunha de agências em todo o território e não contava com recursos para atender devidamente aos financiamentos de prazo longo, de que os agricultores muito necessitavam para a construção 
de benfeitorias, aquisição de veículos, máquinas e outros insumos modernos essenciais à modernização da agricultura (Espírito Santo, 2005). Sobre a situação desses homens e mulheres da terra, Monbeig diz que:

"... estão sob a dependência das grandes empresas nacionais ou estrangeiras. (...). Como são elas as grandes distribuidoras de crédito aos sitiantes, toda a produção algodoeira cai sob o controle de algumas empresas possantes que, por outro lado, são detentoras de uma boa parte das indústrias conexas e são donas do comércio de exportação" (MONBEIG ([1952] 1998, p. 300).

A partir do traçado das estradas de terra construídas no momento cafeeiro, outras foram anexadas, melhorando a fluidez do deslocamento das pessoas e dos produtos agrícolas da zona rural para as cidades (Pinheiro \& Bodstein, 1997). Dos municípios atravessados pela EFNOB- que continuou sendo a espinha dorsal da comunicação regional às outras regiões do espaço geográfico brasileiro e do mundo escoavam-se as mercadorias, principalmente o algodão e seus derivados beneficiados nas indústrias localizadas em Araçatuba e nos municípios de seu entorno. Eram destas cidades onde se contabilizavam os lucros das atividades produtivas e os encaminhavam para seus controladores nas maiores cidades do país e no exterior.

Diversifica-se o meio técnico na região, demandando-se mão-de-obra e consequentemente mercadorias básicas para consumo. Cresce o número de unidades beneficiadoras de produtos agropecuários e fábricas de alimentos durante a década de 1930 (Pinheiro \& Bodstein, 1997). Culturas alimentares intercaladas ao algodão - principalmente arroz, feijão, milho, pecuária leiteira, avicultura e suinocultura - eram praticadas pelos sitiantes, que plantavam para a subsistência e para abastecer com o excedente a demanda regional ${ }^{20}$.

Nas áreas urbanas em ascensão, pequenas fábricas eram acompanhadas
"... pelo movimento de capitais mercantis locais propiciando investimentos de origem privada de companhias de energia, de telefone, de meios-de-transporte, bancos, instituições de ensino, etc. Acrescente-se ainda o surgimento de postos de gasolina, armazéns para venda de implementos agrícolas e sementes, que reforçavam o setor urbano, acelerando a prestação de serviço" (ROSSINI, 1988. p. 74).

Nos anos 1930, os municípios de Araçatuba, Birigui e Penápolis se destacaram como aqueles que apresentaram a maior diversidade e número de empreendimentos. Beneficiamento de café, algodão, e arroz; fiação e tecelagens; curtumes e serrarias; carne, leite e derivados; açúcar, álcool, aguardente, melado e rapadura; vinho e vinagre; massas alimentícias e biscoitos; padarias, confeitarias e pastelarias; derivados de mandioca e milho; balas, chocolates, caramelos, doces em conserva e condimentos; fábricas de calçados, de máquinas agrícolas e de carroças; seleiros e ferreiros e torrefação e moagem de café: são essas as atividades de demanda regional, que em pequena escala, instauraram-se na região. Algumas com caráter ainda artesanal, outras já dentro do espírito da industrialização nascente, ou seja, com o uso das modernas máquinas do momento e uma ascendente divisão social do trabalho (Rego, 1990).

Com o término da ligação ferroviária entre Araçatuba e o Mato Grosso, várias vilas surgiram à beira das estações da Companhia de EFNOB. No entroncamento das estradas de rodagem, longe da estação ferroviária, algumas colônias também cresceram e fundaram povoados: Auriflama, Bilac, Braúna, Buritama, General Salgado e outras.

Em 1940, na Região de Araçatuba, tinha-se 22 aglomerações - municípios e vilas (que como distritos de paz, depois se emancipariam). Possuindo uma população dispersa, que em sua maioria morava nas áreas rurais, no começo dessa década, computava-se 288.474 pessoas. Distribuindo essas aglomerações humanas por classes de população, temos a seguinte distribuição na tabela abaixo: 
Formação sócioespacial da região de

Araçatuba na primeira metade do século XX, pp. 125 - 150

Tabela 1: Distribuição das Aglomerações Humanas na Região de Araçatuba Segundo Classes de População (1940)

\begin{tabular}{|c|c|}
\hline Classes de População & 1940 \\
\hline Até 5 mil & 5 \\
\hline De 5 a 10 mil & 9 \\
\hline De 10 a $20 \mathrm{mil}$ & 3 \\
\hline De 20 a 50 mil & 5 \\
\hline De 50 a 100 mil & - \\
\hline De 100 a 200 mil & - \\
\hline De 200 a 500 mil & - \\
\hline Mais de 500 mil & - \\
\hline
\end{tabular}

Fonte: IBGE, Censo demográfico do Estado de São Paulo de 1940

Em decorrência da expansão da estrada de ferro até o Mato Grosso e o surgimento desses novos povoados, durante a década de 1940, o crescimento demográfico regional se deu principalmente com o desenvolvimento dessas localidades surgidas, onde migrantes e imigrantes as escolheram para fazer a vida.

\section{Segundo Costa \& Wong (1982),}

"A nível de sub-região, observa-se que a ocupação territorial de Andradina se deu na década de 1940, quando sua população passou de pouco menos de 23.000 para 110.000 habitantes, com uma taxa anual média de crescimento de 15,7\%. Esse rápido povoamento se deveu em grande parte à extensão da Estrada de Ferro Noroeste do Brasil, desde Araçatuba até as barrancas do Rio Paraná, na década anterior. A cidade de Andradina, criada em 1937, se tornou pólo urbano de uma nova fronteira agrícola" (COSTA \& WONG, 1982, p. 06).

Assim, comparando a evolução demográfica entre os anos de 1940 e 1950 dos municípios surgidos no começo do século XX com os nascidos no final da década de 1930 na subregião de Andradina, temos o seguinte quadro:
Tabela 2: Região de Araçatuba - População e Taxas Anuais de Crescimento Populacional por Sub-Região (1940-1950)

\begin{tabular}{|c|c|c|c|}
\hline SUB-REEIINES & 19940 & 1950 & $\begin{array}{c}\text { Taxa Anual de Crescimento } \\
1994-1950\end{array}$ \\
\hline Alacatulua & 265.6022 & 313,6000 & 1,660 \\
\hline Andrading & 22,852 & 110.147 & 15,73 \\
\hline Total & 288.474 & 423,827 & 3,85 \\
\hline Estado & $4,02 \%$ & $4,64 \%$ & 2,43 \\
\hline
\end{tabular}

Fonte: IBGE, Censos demográficos do Estado de São Paulo de 1940 a 1950 (COSTA \& WONG, 1982, p. 0506).

Com um aumento anual $(3,45 \%)$ na década de 1940 - maior do que o verificado em todo o estado de São Paulo - , a região como um todo possuía $4 \%$ da população estadual. Imigrantes (principalmente japoneses) e migrantes (principalmente nordestinos) fundaram e povoaram os novos municípios entre Mirandópolis e Castilho (Falleiros, 1999). Entre os municípios mais antigos, alguns tiveram crescimentos anuais maiores que a média sub-regional no período 1940-1950: Auriflama (2,5\%), Buritama (4,6\%) e Araçatuba (3\%): esse último município, o maior da região, o único com mais de 50 mil habitantes, já figurava como pólo regional.

No ano de 1950, com uma ocupação predominantemente rural, a região de Araçatuba possuía 34 aglomerações - entre municípios e distritos de paz - que distribuídas por classes de população, apresentava a seguinte distribuição: 
Tabela 3: Distribuição das Aglomerações Humanas na Região de Araçatuba Segundo Classes de População (1950)

\begin{tabular}{|c|c|}
\hline Classes de População & 1950 \\
\hline Até 5 mil & 8 \\
\hline De 5 a 10 mil & 12 \\
\hline De 10 a 20 mil & 7 \\
\hline De 20 a 50 mil & 6 \\
\hline De 50 a 100 mil & 1 \\
\hline De 100 a 200 mil & - \\
\hline De 200 a 500 mil & - \\
\hline Mais de 500 mil & - \\
\hline
\end{tabular}

Fonte: IBGE, Censo demográfico do Estado de São Paulo de 1950.

Requisitando de grande quantidade de mão-de-obra para os tratos culturais durante o ano todo, o algodão e o café - que teve uma vasta ocupação até a década de 1960, principalmente na sub-região de Andradina (Falleiros, 1999) mantiveram a expansão demográfica na Noroeste Paulista direcionada à zona rural. Sendo o processo produtivo 'na lavoura' dos circuitos espaciais dessas culturas ainda pouquíssimo mecanizado, o trabalho realizado com técnicas manuais em elevada densidade, reproduzia na espacialidade regional a formatação de sistemas de objetos e ações característicos do regime de colonato.

O progresso da cotonicultura continuou em marcha acelerada até 1944. O quinquênio 1940/1944 pode ser considerado o período áureo do algodão em São Paulo, assinalado por suas maiores safras. A safra de 1944 constituiu o recorde absoluto no volume de produção. Já a safra de 1945, teve resultados desastrosos devido ao decurso desfavorável do tempo que naquele ano foi muito adverso. Contudo, foi o poderio norte-americano no controle internacional desse setor o que mais caracterizou a retração da cultura do algodão no estado de São Paulo. Pressionados pelo avolumar contínuo dos seus estoques de algodão e a grande colheita dos países produtores, os Estados Unidos se viram compelidos a adotar uma política agressiva de exportação, com a alegação de constituir o restabelecimento de sua participação histórica no setor. Isso gerou uma redução dos preços internacionais em 1944, o que inibiu as perspectivas futuras dos paulistas em relação a essa cultura.

Com a crise, na Noroeste, o que aconteceu foi uma redução do plantio nas áreas de formação de pastagens. Para abastecer a demanda do mercado interno, manteve-se em menor proporção a oferta da pluma e do caroço dos pequenos produtores às grandes empresas localizadas na região.

\section{A Hegemonização da Pecuária no Uso das Áreas Agrícolas da Região}

Na Noroeste Paulista, em meados do século $X X$, com a crise da cotonicultura, a pecuária bovina se estabeleceu como a cultura com a funcionalidade hegemônica no uso do espaço geográfico regional. Em Monbeig (1998), vemos que "nos arredores imediatos de Araçatuba, desde 1939 podiam ser vistos casas em ruínas, pomares invadidos pelo mato e o gado pastando em velhos cafezais ou em antigos campos de algodão" (MONBEIG ([1952] 1998, p. 314). Esse abandono barateou o preço da terra e propiciou a especulação fundiária com a implantação da pecuária extensiva na região. Abriu-se espaço para um novo ciclo produtivo, que preenchido de início por alguns pecuaristas mineiros, estruturou uma rede de poder regional embasada por fortes vínculos nacionais e, principalmente, com o capital estrangeiro. Na política, por exemplo, essa elite pecuarista em formação, enquanto atora hegemônica direcionadora do uso do espaço geográfico regional, da década de 1940 em diante, elege seus deputados e prefeitos, encaminhando sem empecilhos as atividades do poder público na região. E, assim como as atividades capitalistas anteriores que predominaram na apropriação do espaço geográfico regional, no circuito produtivo da pecuária de corte, a Noroeste Paulista continua a exercer sua função especializada de totalidade parcial do mundo em movimento. 
Formação sócioespacial da região de

Araçatuba na primeira metade do século XX, pp. 125 - 150

Dentre os mineiros, as famílias Maia, Aguiar Ribeiro e Rodrigues da Cunha foram as primeiras a adquirir terras nas redondezas de Araçatuba. Para a região eles passaram a deslocar suas boiadas vindas de Minas Gerais, Mato Grosso e Goiás, com o objetivo de engordá-las antes do abate nos frigoríficos localizados nas proximidades da região metropolitana de São Paulo. Nessa locomoção, feita na maioria das vezes em caravanas, o gado perdia muito peso. Necessitavase de um repouso antes do abate para a recuperação desses animais. Daí a idéia das invernadas nas terras momentaneamente baratas da Noroeste Paulista.

Após a engorda, o gado seguia de trem ou em caravanas margeando pelas estradas de rodagem - como a Marechal Rondon, aberta entre 1940 e 1949 de Bauru à Araçatuba (Carvalho et al, 1992) - até aos abatedouros. Um sistema de crédito oficial mais acessível aos criadores de gado do que aos lavradores; fretes ferroviários mais vantajosos em relação às outras atividades agrícolas; mercado interno cativo com o crescimento da urbanização e aumento da demanda internacional por carne bovina foram motivos que levaram a pecuária à hegemonia na ocupação das terras do oeste paulista (Pigatto, 2001).

Forma-se na região de Araçatuba o maior rebanho do estado ( $20 \%$ do total), que passa a exercer influência fundamental no preço de bovinos em peso de abate em todas as praças do país, popularizando Araçatuba como a capital do boi gordo. Em termos de produtividade agrícola, no campo havia um subaproveitamento das áreas (Costa \& Wong, 1982). Com um ainda pequeno investimento em pesquisa que possibilitasse a melhoria das pastagens, a principal funcionalidade aparentada com a posse e o uso das terras na Noroeste Paulista pela pecuária bovina de corte - onde $40 \%$ das áreas de pastagens se constituíam de propriedades acima de 1.500 ha (Toyama \& Martin \& Tachizawa, 1976) - era a especulação fundiária (Pinheiro, 1980; Sayad, 1977). À espera da valorização de suas terras e de atividades com melhores custos de oportunidade, os produtores mantinham um pastoreio superextensivo, com a presença de áreas apresentando aproximadamente 1 boi para cada 2 hectares (Igreja, 1973).

Reflexo dessa subocupação, adicionada ao fato de que a pecuária é uma atividade que requer pouca mão-de-obra, no decorrer da década de 1950 o crescimento populacional da região passou a se desacelerar. Sem mercado para vender o algodão e o café, parte dos proprietários rurais da sub-região de Andradina, como já se vinha fazendo nas proximidades de Araçatuba, começa a liberar suas terras para o pastoreio do gado. Necessitando de quantidades menores de trabalhadores, desfazse da grande maioria dos colonos antes usados nos tratos da lavoura. Não possuindo emprego suficiente nos setores industrial e de serviços nas áreas urbanas para esses desempregados do campo, a migração para outras regiões do estado e do país foi a saída encontrada por muitos.

Tabela 4: Região de Araçatuba - População e Taxas Anuais de Crescimento Populacional por Sub-Região (1950-1960)

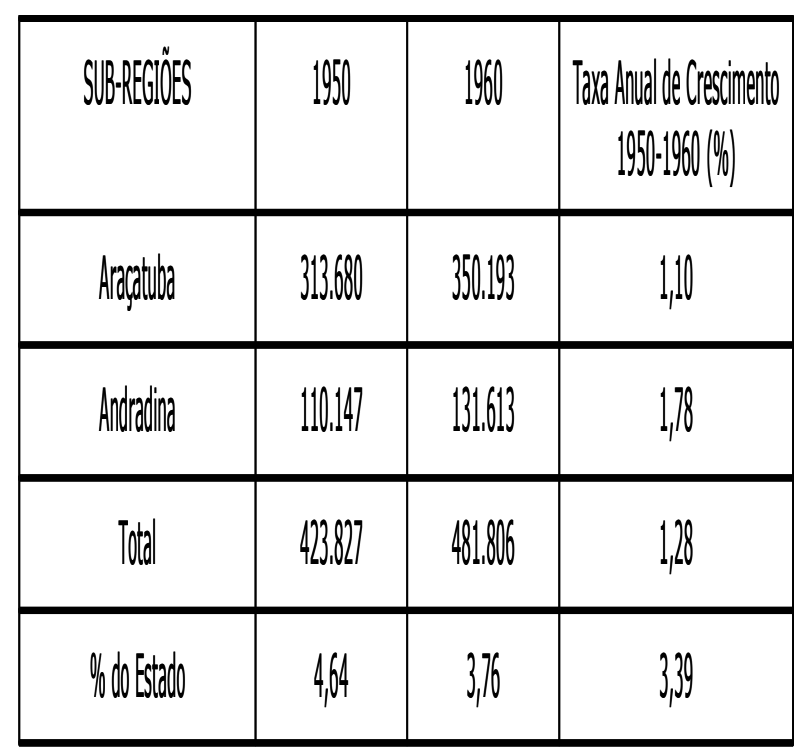

Fonte: IBGE, Censos demográficos do Estado de São Paulo de 1950 a 1960 (COSTA \& WONG, 1982, p. 0506). 
Como se pode observar, entre 1950 e 1960, o crescimento populacional da região, de forma diferente do decênio anterior, foi menor do que o observado no estado de São Paulo. Assim, sua representatividade na população total da província caiu de 4,64 \% para 3,76\%.

Tabela 5: Região de Araçatuba - População e Taxas Anuais de Crescimento Populacional por Sub-Região (1960-1970)

\begin{tabular}{|c|c|c|c|}
\hline SUB-REEGINES & 1960 & 1970 & $\begin{array}{c}\text { Taxa Anual de Crescimento } \\
1960-1070(0 \%)\end{array}$ \\
\hline Anacatuba & 350.193 & 358.842 & 0,24 \\
\hline Andradina & 131.613 & 173.707 & 2,78 \\
\hline Total & 481.806 & 532.549 & 1,00 \\
\hline Yo do Estado & 3,76 & 3,00 & 3,27 \\
\hline
\end{tabular}

Fonte: IBGE, Censos demográficos do Estado de São Paulo de 1960 a 1970 (COSTA \& WONG, 1982, p. 0506).

Durante a década de 1960, o esvaziamento da população continua. Devido à destruição dos resquícios de cafezais que ainda existiam, mais braços de colonos deixam de ser requisitados, acentuando o percentual de pastagens para uma ocupação de $85 \%$ do espaço geográfico regional no final da década, ou seja, 1.540.617 hectares (Camargo, 1983), com um rebanho de 1.373.000 cabeças de gado (Espírito Santo, 2005).

\section{Considerações Finais}

No decorrer das três décadas seguintes (1970-2000) a região sofreria uma perda de dinamismo econômico e social, com a hegemonia perpetuada pela pecuária bovina de corte. Da continuidade do uso extensivo das terras, a maioria dos pecuaristas, sem condições ou interesse em correr riscos com inovações, especulava pelo aparecimento de outras atividades agrícolas com custos de oportunidade mais vantajosos que possibilitassem o uso mais intensivo de suas propriedades ou suas valorizações. Já os mais capitalizados, ao invés de inverterem seus lucros no espaço geográfico regional, aproveitando os estímulos do governo federal para a ocupação do Centro-Oeste e Norte do país (Prodoeste e Sudam), transferiram parte dos seus negócios para essas porções da fronteira agrícola do território brasileiro. Toda esta perda de dinamismo consolidava a região de Araçatuba como aquela de "menor contribuição relativa tanto para a formação do valor da produção agrícola como para o total da área cultivada no oeste paulista e no total do Estado" (VASCONCELOS, 1992, p. 21).

Reflexo dessa situação imposta pelo sistema pecuário foi a limitação do dinamismo industrial na região. Excetuando alguns ramos, como o calçadista em Birigui (Zampieri, 1976), o balanço regional das atividades industriais é apresentado como o menor do estado de São Paulo na década de 1970 . Cadeia produtiva propulsora de pouca diversidade em seu complexo agroindustrial, em Araçatuba, a pecuária, através de seus atores econômicos - os pecuaristas - não inverteu seus capitais de forma expressiva em inovações ou em outras atividades produtivas, geradoras de diversificação e desenvolvimento. Assim, durante todo o período de intenso crescimento econômico mundial e nacional (19671973), quando o interior paulista se torna um espaço geográfico bastante atraente a novos investimentos (Negri, 1996), e com franca expansão do meio técnico-científico no Brasil ${ }^{21}$, a região de Araçatuba, através do conservadorismo e atraso de suas lideranças políticas e econômicas, não se articulou para a recepção dos altos investimentos existentes naquele momento de expansão dos mercados. 
Formação sócioespacial da região de

Araçatuba na primeira metade do século XX, pp. 125 - 150

\section{Notas}

${ }^{1}$ No caso dos fluxos aéreos de aviões, satélites e naves que agregam a informação mediata como um novo pilar técnico essencial à reprodução do capital no atual processo de globalização (Castillo, 1999)

2 Sistemas de objetos são infra-estruturas materializadas na superfície da terra e em sua órbita pelo trabalho humano. Casas, móveis, ruas, avenidas, carros, escolas, prédios, parques, zoológicos, estradas, pontes, viadutos, indústrias, pastos, plantações, máquinas plantadeiras e colheitadeiras, aviões e satélites são alguns poucos objetos formadores e constituintes do sistema geográfico.

3 Sistemas de ações são os fluxos que dão vida aos sistemas de objetos. Disso, compreende-se a impossibilidade de analisar os objetos e as ações isolados uns dos outros. Esses fluxos são impulsionados por intencionalidades humanas, sendo os principais os fluxos de informações, normas, pessoas, capitais e mercadorias (Santos, 2002).

4 Contudo se constata que agrupamentos que nunca tinham tido contatos entre si desenvolveram técnicas parecidas nos tempos primórdios da história da humanidade (Santos \& Silveira, 2001).

${ }^{5}$ Falando sobre o projeto de construção da Estrada de Ferro Noroeste do Brasil (EFNOB), retratou Nelson Werneck Sodré que "A necessidade, vislumbrada pela clarividência de Rio Branco, da ligação ferroviária com a Bolívia, cortando as terras do Oeste, devia contribuir para a abertura e realização, embora retardada, de uma obra singular, que constituiria uma nova componente na geografia humana do Oeste, a estrada de ferro que, partindo de Bauru, no Estado de São Paulo e transpondo o vale do Paraná, chegou à barranca do Paraguai, devendo prolongar-se, através do vale deste último, rumo Corumbá, para atingir, com a parte boliviana, a cidade de Santa Cruz de la Sierra" (SODRÉ, 1990, p. 111). Mais adiante em seu texto, o mesmo autor diz: "A via férrea estabeleceria o elo imprescindível, articulando a região do Oeste ao corpo nacional. Quebraria o perigoso divórcio que vinha na tradição histórica, imposto pelas eventualidades, imperativas da configuração geral da geografia americana. Aproximando a região pastoril do mercado consumidor constituído em São Paulo, pelo adensamento de população que a lavoura cafeeira aí proporcionara e fornecendo o transporte, em troca, do parque industrial paulista ao sertão mato-grossense, dos artigos necessários à vida e ao conforto, a via férrea estabeleceria o mais forte laço de união, desde que o apoiaria na reciprocidade de interesses econômicos" (SODRÉ, 1990, p.151).

${ }^{6}$ Para Prado Jr. (1948), o fim do tráfico negreiro possibilitou uma inversão de capitais dessa atividade para outros setores; permitiu também a normalização das relações com a Grã-Bretanhã, gerando um grande aumento dos fluxos de capitais dessa e de suas nações parceiras ao Brasil.

7 Dando ênfase às contradições desse processo de mecanização do território brasileiro, Santos \& Silveira (2001), mostrando a prioridade dos interesses estrangeiros nesses trajetos da circulação mecanizada, disseram que "a busca da integração nacional não era um imperativo da construção dessas redes" (SANTOS \& SILVEIRA, 2001. p. 21).

${ }^{8}$ Ferrovia que atravessará a região onde se localiza o estudo de caso deste trabalho.

1 Com isso, reproduz-se ideologicamente a produção de um imaginário geográfico destinado a legitimar a efetiva ocupação da 'civilização' e modernidade a ocorrer no futuro (Magnoli, 1996).

9 Nessa década, a cidade de Bauru começa a passar por transformação administrativa importante, transpondo seu gerenciamento hegemônico, de maneira conflitiva até a década 
de 1910, das mãos da Igreja à uma estrutura laica representante do capital cafeeiro. Como "boca do sertão", localizada no centro da província paulista, recebe em um primeiro momento a convergência dos trilhos das Companhias Paulista e Sorocabana. Em um segundo momento, exercerá a nobre função de entreposto controlador dos fluxos estabelecidos após a construção da Companhia Noroeste do Brasil. (Ghirardello, 2000).

10 Com a decadência da escravatura, a renda capitalizada dos fazendeiros deixa de se configurar na posse de escravos. É a posse da terra, e principalmente das riquezas comerciáveis nela produzidas, que passa a ser a garantia na obtenção de crédito por parte dos fazendeiros: "Em 1873, o governo estendera o crédito hipotecário a todos os municípios da província de São Paulo, Paraná e Santa Catarina, tendo como suporte a fazenda, representada sobretudo pelas plantações e pelas instalações. Esse procedimento é seguramente uma das causas da intensificação da expansão do café em direção ao oeste de São Paulo, para a região de Campinas e mais além." (MARTINS, 1996, p.30).

11 Mesmo sem documentação, esses poucos herdeiros que nem mais moravam na antiga colônia (moravam nas proximidades de São José do Rio Preto e Bauru) - pois foram expulsos pelos índios caingangues - podiam ser considerados legalmente como donos das terras da região. Nessa transação, quando Cruz descobriu as posses daquela gente, foi de casa em casa tomando procuração de todos para levantamento e legislação das terras apossadas, recebendo a metade delas em pagamento. Ghirardello (2000) relata que: "Dessa maneira Bento da Cruz consegue amealhar uma quantidade de terra estimada em 30 mil alqueires, em boa parte acompanhando a linha da C.E.F.N.O.B." (GHIRARDELLO, 2000, p. 78).

${ }^{12}$ Para reforçar o momento histórico adentrado pelo país, GHIRARDELLO (2000, p. 78) cita PRADO JR: "nenhum dos freios que a moral e a convenção do império antepunham ao espírito especulativo e de negócios subsistirá; a ambição do lucro e do enriquecimento consagrar-se-á como um alto valor social" (PRADO JR., 1994, p.208).

${ }^{13} \mathrm{Com}$ dimensões a partir de 10 alqueires, pagos parceladamente, $30 \%$ à vista e o restante em 3 anos com juros de $10 \%$. Seu público foram prioritariamente imigrantes italianos que já tinham guardado algum dinheiro, principalmente nas roças de café da região de Ribeirão Preto (MONBEIG, 1998).

${ }^{14} \mathrm{~A}$ ocupação do café se dava no espigão divisor de águas dos rios Feio e Tietê, ficando as pastagens nas áreas mais baixas, junto às várzeas dos rios. Evitava-se o plantio do café nos fundos de vale para evitar a perda da produção com as geadas (Monbeig, 1998).

${ }^{15}$ Contudo, podemos considerar, nas políticas agrícolas, que o governo da Revolução de 1930 e os posteriores até 1960 foram limitados, pois não implementaram reformas como as acontecidas nos países centrais do capitalismo no que se refere à estrutura técnica e fundiária. Para se ter uma idéia, as burguesias industriais do mundo desenvolvido viram na concentração de terras um resquício feudal que impedia o desenvolvimento do capitalismo, e promoveram a reforma agrária em seus territórios. No Brasil, aconteceu diferente. A burguesia industrial passa a ter o poder político para a realização dessas reformas, configurado na instalação do modelo de substituição de importações estimulador e fortalecedor da indústria nacional e do mercado interno. Contudo, no que se refere à reforma agrária, essa burguesia industrial não agiu como nos países desenvolvidos. Segundo Martins (1997), "Entre as velhas elites e as novas elites estabelecera-se uma espécie de compromisso político, mediante o qual os industriais e os grandes comerciantes tornaramse grandes clientes políticos das oligarquias, às quais delegaram suas responsabilidades de mando e direção, reproduzindo os mesmos mecanismos políticos que vitimavam todo o povo e impediam um efetivo desenvolvimento" (MARTINS, 1997, 20). Sobre essa mesma realidade, Sorj (1982) relata: "A situação que se configura a partir de 1930 é o deslocamento dos grandes proprietários 
Formação sócioespacial da região de

Araçatuba na primeira metade do século XX, pp. 125 - 150

rurais da direção do Estado, visto que tanto as políticas econômicas quanto o conjunto da estrutura política se centram agora no setor urbano-industrial. Esse deslocamento, porém, não chega a eliminar os grandes proprietários fundiários da estrutura política, que permanecem no bloco do poder, mas em uma posição subordinada" (SORJ, 1982, p. 21). Essa força mantida pela oligarquia rural brasileira possibilitou conquistas frente ao novo governo estabelecido. Em Espírito Santo (2005) é mostrado que: "Após a 'Revolução de 30', o Estado definitivamente age em nível federal e aplica políticas de fomento e apoio, criando ou readequando instituições e órgãos governamentais, os quais vieram a compor um forte esquema de apoio aos interesses da oligarquia rural" (ESPIRITO SANTO, 2005, p.46).

${ }^{16}$ Além dos planos do primeiro governo getulista, o autor analisou o Plano Salte (1950-1954), o Plano de Metas (1956-1961) e o Plano Trienal de Desenvolvimento Econômico e Social e o Plano de Ação Econômica do Governo (PAEG - 19641966).

${ }^{17}$ Usando a infra-estrutura recebida do período cafeeiro, na região de Araçatuba o algodão se desenvolveu principalmente em pequenas propriedades, sendo também plantado em grandes áreas na formação de pastos para as invernadas. "A meação desenvolveu-se paralelamente ao arrendamento e, finalmente, conquistou o fazendeiro, no momento em que a criação de gado revelou-se um excelente negócio.
(...) Já vimos como se distribuíam as formas de ocupação do solo nas grandes fazendas, por exemplo na fazenda Aguapeí, que além do cafezal, tem mais de 11.000 hectares de campos em desflorestamento. Essas pastagens recentes e derrubadas atuais são obras de meeiros plantadores de algodão" (MONBEIG, 1998, p. 286).

${ }^{18}$ Foram anexações inovadoras ao espaço geográfico regional do processo de industrialização brasileiro. Foi a totalização parcial de um novo momento, onde dos fixos urbano-industriais materializados pela intencionalidade de interesses longínquos se passam a comandar com maior rigidez o funcionamento dos sistemas de objetos e ações das áreas rurais.

${ }^{19} \mathrm{O}$ Japão vivia uma crise econômica com uma superpopulação. Isso acarretou uma emigração para várias regiões do mundo, principalmente para o Brasil (NOGUEIRA, 1973).

${ }^{20} \mathrm{O}$ café também continuou sendo plantado em menores quantidades após 1929 na Noroeste. Até a década de 1960, manteve uma ocupação ao redor de $30 \%$ das áreas regionais (REGO, 1990).

${ }^{21}$ Segundo Assumpção (1984), o I PND (Plano Nacional de Desenvolvimento), implementado entre os anos de 1972 e 1974, tinha como um dos pontos principais "desenvolver a agricultura moderna em bases industriais na região CentroSul" (ASSUMPÇÃO, 1984, p. 21).

\section{Bibliografia}

ARAÚJO NETO, A. C. "Entre a Revolução e o Corporativismo: a experiência sindical dos funcionários da E. F. Sorocabana nos anos 1930" Dissertação de Mestrado. FFLCH. USP. São Paulo, 2006.

CAMARGO, A. M. M. P. de. "Substituição Regional entre as Principais Atividades Agrícolas no Estado de São Paulo". Dissertação de Mestrado. ESALQ. Piracicaba, 1983.
CARVALHO, F. C. et al. "Avaliação do potencial agroindustrial das divisões regionais agrícolas de Araçatuba e Presidente Prudente, estado de São Paulo", Agricultura em São Paulo, vol. 39, supl. 1, Secretaria da Agricultura e Abastecimento do estado de São Paulo, Instituto de Economia Agrícola (IEA), São Paulo, 1992.

CAVENAGHI, A. J. "Olhos do barão, boca do sertão: uma pequena história da fotografia e da cartografia 
no noroeste do território paulista (da segunda metade do século XIX ao início do século XX)". Tese de Doutorado. FFLCH. USP. São Paulo, 2004.

COSTA, L. B. \& WONG, L. R. "Análise Demográfica Regional - Região de Araçatuba: Uma Área de Esvaziamento Populacional?". SEADE. São Paulo, 1982.

CRUZ, T. F. S. "Paranapiacaba: a Arquitetura e o Urbanismo de uma Vila Ferroviária" Dissertação de Mestrado. EESC. USP. São Carlos, 2007.

ESPÍRITO SANTO, C. R. "Dinâmica do Desenvolvimento Rural na Região de Araçatuba (SP)". Tese de Doutorado. FCT. UNESP. Presidente Prudente, 2005.

FALLEIROS, A. "Mirandópolis: Sua evolução no Século XX". Gráfica Dom Bosco, Três Lagoas, 1999.

FURTADO, C. "Formação Econômica do Brasil". Fundo de Cultura. Rio de Janeiro, 1959.

GHIRARDELLO, N. "À beira da linha: formações urbanas da noroeste paulista" - Tese de Doutorado - Faculdade de Arquitetura e Urbanismo (FAU), USP, São Paulo, 1999.

HOLANDA, S. B. de. "Caminhos e Fronteiras". Companhia das Letras. 3a edição. São Paulo, 1994.

INSTITUTO BRASILEIRO DE GEOGRAFIA E ESTATÍSTICA - IBGE. Censo demográfico: 1940. Rio de Janeiro: IBGE, 1940.

IBGE, 1950

. Censo demográfico: 1950. Rio de Janeiro: IBGE, 1960.

Censo demográfico: 1960. Rio de Janeiro:

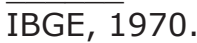

Censo demográfico: 1970. Rio de Janeiro: . Censo demográfico: 1980. Rio de Janeiro: IBGE, 1980
IGREJA, A. C. M. "Evolução da Pecuária Bovina de Corte no Estado de São Paulo (1969-1984)". Dissertação de Mestrado. ESALQ. Piracicaba, 1987.

MAGNOLI, D. M. "Corpo da Pátria: Imaginação Geográfica e Política Externa no Brasil (18081912)". Tese de Doutorado. Departamento de Geografia. FFLCH. USP. São Paulo, 1996.

MANFREDI NETO, P. "O trem da morte - o imaginário do progresso na Noroeste (19051930)". Dissertação de Mestrado. FFLCH. USP. São Paulo, 1995.

MARTINS, J. S. "O cativeiro da terra". Hucitec. $6^{a}$ edição. São Paulo, 1996.

"Fronteira: a degradação do outro nos confins do humano". Hucitec. São Paulo, 1997.

MARTINS, O. \& RAMOS, D. S. "A Cidade-pérola em Capítulos". Tipografia Noroestina Ltda. Araçatuba, 1961.

MONBEIG, P. "Pioneiros e fazendeiros de São Paulo". 2a edição. Hucitec-Polis. São Paulo, [1952] 1998.

MUSSOLINI, G. "Os meios de Defesa contra a Moléstia e a Morte em duas Tribos Brasileiras Kaingangues e Bororo" Dissertação de Mestrado. ESP. USP. 1946.

NEGRI, B. "Desconcentração da indústria paulista nos últimos vinte anos (1970-1990)". Anais do XXI Encontro Nacional de Economia, Campos do Jordão, 1992.

NOGUEIRA, A. R. "A Imigração Japonesa para a Lavoura Cafeeira Paulista (1908-1922)". Instituto de Estudos Brasileiros (IEB). São Paulo, 1973.

PIGATTO, G. "Determinantes da Competitividade da Indústria de Carne Bovina do Estado de São Paulo". Dissertação de Mestrado. UFSCAR. São Carlos, 2001.

PINHEIRO, F. A. "A Renda e o Preço da Terra: Uma Contribuição à Análise da Questão Agrária 
Formação sócioespacial da região de

Brasileira". Tese de Livre-Docência. ESALQ-USP. Piracicaba, 1980.

PINHEIRO, C. \& BODSTEIN, O. "História de Araçatuba". Academia Araçatubense de Letras. Araçatuba, 1997.

PRADO JR, C. "História Econômica do Brasil". 42a ed.. São Paulo, Brasiliense, 1994.

QUEIROZ, P. R. C. "Uma ferrovia entre dois mundos: a E.F. Noroeste do Brasil na construção histórica de Mato Grosso (1918-1956)". Tese de Doutorado. FFLCH. USP. São Paulo, 1999.

REGO, M. T. R. "Proálcool na região de Araçatuba: o doce fel do binômio cana-boi". Tese de Doutorado. FFLCH, USP, São Paulo, 1990.

ROSSINI, R. E. "Geografia e Gênero: A mulher na lavoura canavieira paulista". tese de livredocência. FFLCH. USP. São Paulo, 1988.

SAES, F. A. M. de. "As ferrovias de São Paulo: 1870-1940". Hucitec. São Paulo, 1981.

SANTOS, M. "Por Uma Geografia Nova". Hucitec. São Paulo, 1978.

. "Metamorfoses do Espaço Habitado".

Hucitec. São Paulo, 1988.

. "Técnica, espaço, Tempo: globalização

e meio técnico-científico-informacional". Hucitec, São Paulo, 1994.

. "A Urbanização Brasileira". Hucitec, São

Paulo, 1994b.

. "Por uma outra globalização". Record.

São Paulo, 2000.
. "Natureza do Espaço: técnica e tempo, razão e emoção". Editora da Universidade de São Paulo. São Paulo, 2002.

. "O espaço dividido: os dois circuitos da economia urbana dos paises subdesenvolvidos". Editora da Universidade de São Paulo. São Paulo, 2002b.

- "Economia Espacial: Críticas e

Alternativas". Editora da Universidade de São Paulo. São Paulo, 2003.

SANTOS, M. \& SILVEIRA, M. L. "O Brasil: Território e Sociedade no Início do Século XXI". Editora Record. Rio de Janeiro, 2001.

SAYAD, J. "Preço da Terra e Mercados Financeiros". Pesquisa e Planejamento Econômico, vol. 7, nº. 3, São Paulo, Dez. 1977, pp. 623-662.

SILVEIRA, M. L. "Um País, Uma Região: Fim de século e modernidades na Argentina". FAPESP. São Paulo, 1999.

SORJ, B. "Camponeses e Agroindústria: Transformação social e representação política na avicultura brasileira.". Ed. Zahar. Rio de Janeiro, 1982.

SODRÉ, N. W. "Oeste: Ensaio Sobre a Grande Propriedade Pastoril". Arquivo do Estado de São Paulo. São Paulo, 1990.

TOYAMA, N. K. \& MARTIN, N. B. \& TACHIZAWA, E. H. "A Pecuária Bovina de Corte no Estado de São Paulo". Agricultura em São Paulo. Instituto de Economia Agrícola. Secretaria da Agricultura do Estado de São Paulo. São Paulo, 1976. 
TRAVASSOS, Mario. Projeção Continental do Brasil. São Paulo: Nacional, 1938.

VASCONCELOS, L. A. T. "Desenvolvimento econômico e urbanização nas Regiões Administrativas de São José do Rio Preto e de Araçatuba". Dissertação de Mestrado - Instituto de Economia, Universidade Estadual de Campinas, Campinas, 1992.

ZAMPIERI, H. "Birigui, cidade industrial do oeste paulista: um núcleo recente de fabricação do calçado". Dissertação de Mestrado, FFLCH, USP, São Paulo, 1976.

Trabalho enviado em outubro de 2009 Trabalho aceito em maio de 2010 